\title{
General heat transfer correlations for flow boiling of zeotropic mixtures in horizontal plain tubes
}

Zhang, Ji; Mondejar, Maria E.; Haglind, Fredrik

Published in:

Applied Thermal Engineering

Link to article, DOI:

10.1016/j.applthermaleng.2019.01.036

Publication date:

2019

Document Version

Peer reviewed version

Link back to DTU Orbit

Citation $(A P A)$ :

Zhang, J., Mondejar, M. E., \& Haglind, F. (2019). General heat transfer correlations for flow boiling of zeotropic mixtures in horizontal plain tubes. Applied Thermal Engineering, 150, 824-839.

https://doi.org/10.1016/j.applthermaleng.2019.01.036

\section{General rights}

Copyright and moral rights for the publications made accessible in the public portal are retained by the authors and/or other copyright owners and it is a condition of accessing publications that users recognise and abide by the legal requirements associated with these rights.

- Users may download and print one copy of any publication from the public portal for the purpose of private study or research.

- You may not further distribute the material or use it for any profit-making activity or commercial gain

- You may freely distribute the URL identifying the publication in the public portal 


\title{
General heat transfer correlations for flow boiling of zeotropic mixtures in horizontal plain tubes
}

\author{
Ji Zhang*, Maria E. Mondejar, Fredrik Haglind
}

Department of Mechanical Engineering, Technical University of Denmark, Nils Koppels Allé, Building 403, 2800 Kongens Lyngby, Denmark

\section{Abstract}

A general heat transfer correlation to predict the thermal performance of zeotropic mixture flow boiling is essential for an optimal evaporator design in thermodynamic cycles using zeotropic mixtures as working fluids. This work aims at developing a new general correlation to predict the flow boiling heat transfer of zeotropic mixtures in horizontal plain tubes with a significantly better predictive performance than those of the existing correlations. In order to achieve this goal, a database containing 2091 experimental data points of macroscale flow boiling experiments with zeotropic mixtures in horizontal plain tubes from 22 independent research groups was collected. The predictive performances of the existing correlations were evaluated by comparing the predicted values calculated by the existing correlations with the experimental data points. Based on an analysis of the physical phenomena and on the results of the comparison of the existing correlations, two new heat transfer correlations were derived by following two different approaches: i) modifying existing correlations and introducing a new dimensionless number (the ratio of the temperature glide of the mixture to the saturation temperature), and ii) using dimensionless analysis coupled with multiple regression. The comparison results for the existing correlations indicate that most of the correlations overestimate the heat transfer coefficient, and only three correlations present a mean absolute percentage deviation below $50 \%$, the lowest being $44.2 \%$. The results suggest that the new correlation developed following the first approach, yields a mean absolute percentage deviation of $29.0 \%$, while the correlation developed by following the second approach yields a mean absolute percentage deviation of $24.6 \%$.

Keywords: flow boiling, zeotropic mixture, heat transfer correlation, thermodynamic cycle

* Corresponding author. Tel.: +45 4525 13 87; fax: +45 45251961

E-mail address: jizhang@ mek.dtu.dk (Ji Zhang) 


\begin{tabular}{|c|c|c|c|}
\hline \multicolumn{4}{|c|}{ Nomenclature } \\
\hline \multicolumn{2}{|l|}{ Symbols } & \multicolumn{2}{|c|}{ Subscripts } \\
\hline$B$ & $\begin{array}{l}\text { scaling factor used in Eq. (14) for Thome mixture } \\
\text { correction factor }\end{array}$ & SA & $\begin{array}{l}\text { Stephan and Abdelsalam } \\
\text { correlation }\end{array}$ \\
\hline$B d$ & product of Laplace constant and equilibrium break- & $\mathrm{b}$ & bubble point \\
\hline & off-diameter, m & Cooper & Cooper correlation \\
\hline Bo & Boiling number & c & critical \\
\hline$c_{p}$ & specific heat capacity, $\mathrm{J} / \mathrm{kg} \mathrm{K}$ & $\mathrm{cb}$ & convective boiling \\
\hline$D$ & tube diameter, $\mathrm{m}$ & $\mathrm{d}$ & dew point \\
\hline$F$ & enhancement factor & $\mathrm{g}$ & temperature glide \\
\hline$F_{c}$ & Thome mixture correction factor; see Eq. (14) & id & ideal \\
\hline $\mathrm{Fr}$ & Froude number & 1 & liquid \\
\hline$G$ & mass flux, $\mathrm{kg} / \mathrm{m}^{2} \mathrm{~s}$ & lo & liquid only \\
\hline$H$ & heat transfer coefficient, $\mathrm{W} / \mathrm{m}^{2} \mathrm{~K}$ & $\mathrm{~m}$ & mean \\
\hline$h_{f g}$ & latent heat of vaporization, $\mathrm{J} / \mathrm{kg}$ & $\operatorname{mix}$ & mixture \\
\hline$H$ & enthalpy, J/kg & $\mathrm{nb}$ & nucleate boiling \\
\hline$K$ & thermal conductivity, W/m K & pool & pool boiling \\
\hline$M$ & molecular weight & sat & saturation \\
\hline$P$ & pressure, $\mathrm{kPa}$ & tp & two phase \\
\hline $\operatorname{Pr}$ & Prandtl number & $\mathrm{v}$ & vapor \\
\hline$P_{r}$ & reduced pressure & vo & vapor only \\
\hline Q & heat flux, W/m² & 1 & more volatile component \\
\hline$Q^{*}$ & $\begin{array}{l}\text { ratio between sensible heat and latent heat in a } \\
\text { complete flow boiling process; see } \varphi_{9} \text { in Eq. (31) }\end{array}$ & \multicolumn{2}{|c|}{ Greek Symbols } \\
\hline $\operatorname{Re}$ & Reynolds number & $\sigma$ & surface tension, $\mathrm{N} / \mathrm{m}$ \\
\hline$S$ & suppression factor & $\beta$ & contact angle in Eq. $(8),{ }^{\circ}$ \\
\hline$T$ & temperature, $\mathrm{K}$ & $\beta_{l}$ & liquid-phase mass transfer \\
\hline We & Weber number & & coefficient in Eq. (14) \\
\hline$X$ & molar fraction & $\Pi$ & dimensionless term in Eq. (30) \\
\hline$X$ & vapor quality & $\varphi$ & dimensionless term in Eq. (33) \\
\hline$X_{t t}$ & Martinelli number & $\mu$ & dynamic viscosity, $\mathrm{Pa} \cdot \mathrm{s}$ \\
\hline$\tilde{x}$ & molar composition in liquid phase & $\rho$ & density, $\mathrm{kg} / \mathrm{m}^{3}$ \\
\hline Y & a factor in Bell-Ghaly method; see Eq. (16) & $\Delta$ & difference \\
\hline$\tilde{y}$ & molar composition in vapor phase & & \\
\hline \multicolumn{4}{|c|}{ Abbreviations } \\
\hline MAPD & mean absolute percentage deviation & & \\
\hline MBPD & mean bias percentage deviation & & \\
\hline PCT30 & $\begin{array}{l}\text { percentage of data points within } \pm 30 \% \text { of the } \\
\text { prediction }\end{array}$ & & \\
\hline PCT50 & $\begin{array}{l}\text { percentage of data points within } \pm 50 \% \text { of the } \\
\text { prediction accuracy of }\end{array}$ & & \\
\hline
\end{tabular}




\section{Introduction}

Today working fluid mixtures are widely used in refrigeration systems and heat pumps [1], and their utilization in organic Rankine cycle power systems is being introduced to a greater extent [2]. In refrigeration systems and heat pumps the main benefits of working fluid mixtures lie in the expansion of the availability of working fluids for system optimization, the compensation of undesirable properties of one of the components (e.g. flammability, global warming potential), as well as on the performance increase due to the improved temperature matching between the fluids exchanging heat [3]. In organic Rankine cycle power systems, the temperature glide represents the main advantage of their use, as it contributes to reduce irreversibilities during the phase change, resulting in better thermodynamic performance.

The use of mixtures as working fluids started in the early 1990s, driven by the imminent phase-out of the widely used chlorofluorocarbon refrigerants (e.g. R11, R12) and the lack of adequate pure-fluid alternatives [4]. Since then, the use of mixtures as replacements of working fluids with poor environmental characteristics has been sustained by the consequent phase-out of hydrochlorofluorocarbons, and more recently, hydrofluorocarbons. In this context, mixing different fluid components offers an additional degree of freedom to obtain optimal fluid properties, including thermophysical properties (e.g. boiling temperature, density, thermal conductivity), safety properties (e.g. toxicity, flammability), and environmental properties (e.g. global warming potential, ozone depletion potential).

A general heat transfer correlation capable of predicting accurately the heat transfer coefficient of zeotropic mixtures flow boiling is essential for modeling and designing evaporators using mixtures as working fluids. Numerous mixture flow boiling correlations have been developed in the last decades; however, most of them were developed based on limited experimental data from one or a few research works. Consequently, such correlations typically do not provide accurate predictions for a wide range of operating conditions [5]. For example, a well-known correlation developed by Jung et al. [6] using experimental results of the fluid mixtures R22/R114 and R12/R152a failed to predict the test data from other independent research groups, i.e. deviations of $54 \%, 116 \%$ and $62 \%$ were reported by Rabah and Kabelac [7] for propane/R134a, by Chiou et al. [8] for R22/R124 and by Grauso et al. [9] for $\mathrm{CO}_{2}$ /Propane, respectively. Currently, the poor predictive performance of existing heat transfer correlations hinders the development of thermodynamic cycles using zeotropic mixtures. Therefore, a general correlation, validated over a wide range of experimental data of zeotropic mixtures, is needed [10]. 
The objective of this paper is to develop a general heat transfer correlation for zeotropic mixtures that provides a significantly better predictive performance than existing correlations. To this end, a database including all experimental data for flow boiling of zeotropic mixtures was compiled. First, the predictive performances of the existing correlations were evaluated by comparing the predicted values calculated by the existing correlations with the experimental data points. Second, new heat transfer correlations for zeotropic mixtures' flow boiling were developed using two different approaches: i) modifying existing correlations and introducing a new dimensionless number (the ratio of the temperature glide of the mixture to the saturation temperature), and ii) using dimensionless analysis coupled with multiple regression.

It is well known that heat transfer correlations differ significantly for different geometries of the heat transfer equipment and for different heat transfer regimes (e.g. large differences between the formulations for pool boiling and in-tube flow boiling exist). In this paper, the scope was limited to include macroscale flow boiling of zeotropic mixtures in horizontal plain tubes, as this represents the most common heat transfer process in commercial evaporators [11] and the majority of research works on mixture flow boiling. A macroscale-to-microscale transition criterion developed by Kew and Cornwell [12] was employed to evaluate the scale of the heat transfer process. Accordingly, microscale flow, azeotropic and near-zeotropic mixtures (see Section 2.1) and tubes with enhanced structure and/or vertical configurations were not considered. Furthermore, the scope of the paper is limited to include heat transfer processes in tubular heat exchangers, in which the working fluid boils inside the tubes. Such heat transfer process is representative for shelland-tube heat exchangers, which is the heat exchanger configuration most commonly used in industry [13]. Shell-and-tube heat exchangers are widely used as evaporators (boiling inside the tubes) in refrigeration and air conditioning systems [11], heat pumps [13] and organic Rankine cycle systems [14]. The mixture flow boiling correlation developed in this paper can be used to calculate the tube-side heat transfer coefficient, which (along with the shell-side heat transfer coefficient) is needed to compute the overall heat transfer coefficient, enabling the sizing of the heat exchanger [15].

This paper proceeds with a description of the theoretical foundation in Section 2. The database collection and the evaluation of the predictive performance of the existing correlations are presented in Sections 3 and 4, respectively. Section 5 addresses the development of the new heat transfer correlations. Section 6 reports the conclusions of the study.

\section{Theoretical foundation}

The necessary fundamental knowledge for this work is presented in this section, providing the 
theoretical background for the development of the new heat transfer correlations.

\subsection{Zeotropic mixtures}

Fluid mixtures are often classified into two groups, azeotropic mixtures and zeotropic mixtures, depending on their vapor-liquid equilibrium properties. Azeotropic mixtures exhibit identical mass fraction compositions of the liquid and the vapor phase at specific temperatures and pressures, and the temperature glide $T_{\mathrm{g}}$ (i.e. difference between the bubble and dew temperatures of the bulk mixture) is null [4]. On the contrary, the composition of the vapor and liquid phases in zeotropic mixtures varies with the temperature, pressure and vapor quality, and exhibits a temperature glide that tends to increase with the difference in boiling temperatures of the mixture components. This behavior can be easily observed in temperature - composition $(T-X)$ diagrams, where the upper and bottom lines represent the dew and bubble temperature lines, respectively, as functions of the mixture molar composition (see Figure 1). Figure 1.a depicts an example $T$ - $X$ diagram for binary mixtures with zeotropic behavior, and Figure 1.b depicts an example of binary mixtures that present an azeotropic point at molar fraction $X_{\mathrm{a}}$. For a mixture with composition $X_{1}$, the molar compositions in the vapor and liquid phases at a temperature between $T_{\mathrm{b}}$ and $T_{\mathrm{d}}$ are obtained as $\tilde{y}_{1}$ and $\tilde{x}_{1}$, respectively. For the azeotropic mixture with composition $X_{\mathrm{a}}, T_{\mathrm{d}}$ coincides with $T_{\mathrm{b}}$. There is also a group called near-azeotropic mixtures referring to zeotropic mixtures in which the temperature glide is small enough to be neglected. However, the limit in temperature glide to define a near-azeotropic mixture is unclear, ranging from $0.6 \mathrm{~K}$ according to Mohanraj et al. [1] to a $10{ }^{\circ} \mathrm{F}$ (or $5.55 \mathrm{~K}$ ) according to the Environmental Protection Agency [16]. With regards to Figure 1.b, the compositions within the shaded area represent mixtures that could be considered as near-azeotropic.

a)

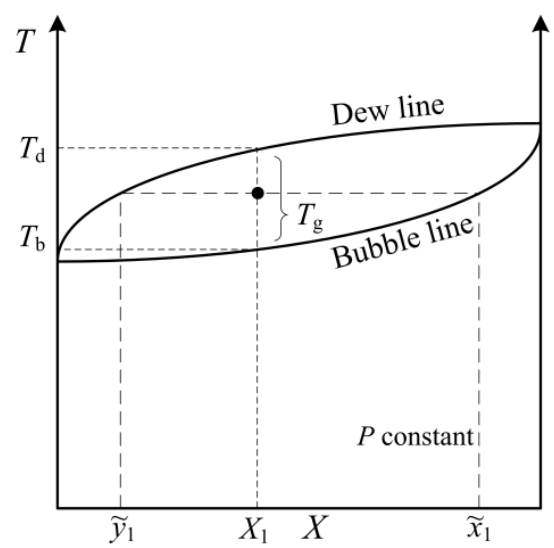

b)

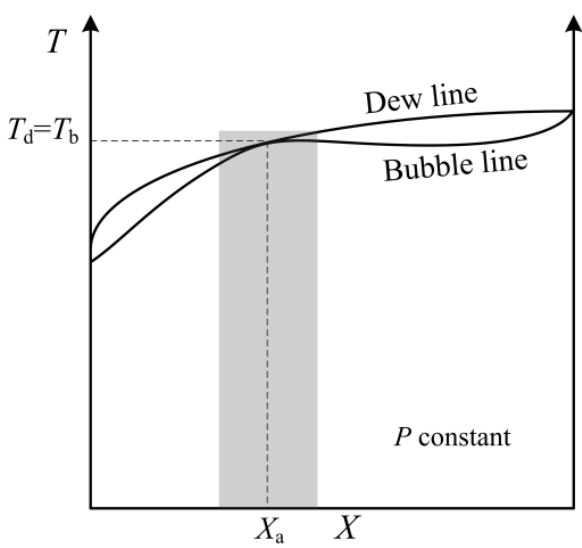

Figure 1 Examples of temperature - composition $(T-X)$ diagrams for (a) mixtures showing zeotropic behavior and (b) mixtures showing an azeotrope at composition $X_{\mathrm{a}}$. The dew and bubble lines are represented for a single pressure. $T_{d}$ and $T_{b}$ are the dew and bubble temperatures, respectively, corresponding to a mixture molar fraction $X_{1}$. 
Given that azeotropic mixtures represent only a small portion of all the possible compositions

2 of working fluid mixtures, and near-azeotropic mixtures exhibit still a finite temperature glide, the scope of this paper is limited to consider zeotropic and near-azeotropic mixtures. As a matter of fact, most of the available heat transfer data for working fluid mixtures correspond to blends with temperature glides of more than $5 \mathrm{~K}$; see the statistics of the temperature glide of the mixtures in Figure 2 in Section 3.

\subsection{Mixture flow boiling}

The heat transfer in flow boiling is governed by nucleate boiling and convective boiling. Nucleate boiling has a similar heat transfer mechanism as that of pool boiling, in which the heat transfer process is highly related to the bubble dynamics. More specifically, the boiling process includes the bubble's formation in the nucleation site, its departure from the wall, growth, merging and collapse. In convective boiling, the process of boiling is replaced by evaporation, taking place at the liquid-vapor interface due to the heat transfer through convection across a flowing liquid film along the wall.

It is well known that the use of a zeotropic mixture as working fluid instead of a pure fluid causes a significant heat transfer degradation. For nucleate boiling, the weakened heat transfer performance results mainly from the mass transfer resistance and the loss of effective superheat $[6,17]$. This phenomenon is exemplified for a binary mixture as follows. At the interface where the bubble is growing, the concentration of the less volatile component in the liquid phase is richer than in the bulk liquid, thereby causing a higher bubble point at the bubble interface than in the bulk liquid. Consequently, the effective superheat driving the vaporization decreases. Moreover, the more volatile component from the bulk liquid has to diffuse through the depleted region surrounding the bubble as the bubble growth continues, resulting in an additional mass transfer resistance compared with the case for pure working fluids. For convective boiling, such mass transfer resistance also appears at the evaporation interface, however, the mixture mass diffusion effect is less pronounced compared with that in nucleate boiling [18,19]. In addition, another two important reasons for the heat transfer degradation in convective boiling are i) the smaller values of the mixture physical properties compared to the ideal values (which are obtained by linear interpolation between the physical properties of the two pure-fluid components) $[6,18,20]$, and ii) the additional sensible heat transfer to the liquid and vapor phases due to the increase of the bubble point temperature along the flow direction caused by the variation of the liquid-phase composition [10], weakening the performance of the boiling process compared to a pure latent heat transfer process in isothermal vaporization of a pure working fluid. 
The temperature glide $T_{g}$ also has a significant effect on the heat transfer process, especially the one governed by nucleate boiling. This is attributed to the larger mass transfer resistance caused by a larger temperature glide of the mixture, hence suppressing the nucleate boiling. Therefore, the larger the temperature glide, the more the contribution of the nucleate boiling degrades [21]. Even a full suppression of nucleate boiling has been observed in flow boiling of zeotropic mixtures [6].

\subsection{Overview of flow boiling heat transfer correlations}

In this section, the flow boiling heat transfer correlations available in the open literature for both pure and mixed fluids are reviewed. Flow boiling heat transfer correlations for pure working fluids are usually developed based on three models: the superposition model (SM), the asymptotic model (AM) and the enhancement model (EM) [22]. The superposition model, which was firstly applied by Chen [23], can be generally defined as

$$
h_{t p}=h_{n b}+h_{c b},
$$

where the two-phase heat transfer coefficient $h_{t p}$ is calculated as the sum of the nucleate boiling $h_{n b}$ and convective boiling $h_{c b}$ contributions. By refining the two contributions, the superposition model can be further defined as

$$
h_{t p}=S h_{p o o l}+F h_{l}
$$

where $h_{l}$ and $h_{\text {pool }}$ are the liquid single-phase convective and pool boiling heat transfer coefficients, respectively. The enhancement factor $F$ and suppression factor $S$ account for the intensified convective heat transfer of the two-phase flow with respect to the liquid single-phase and the suppression of bubble nucleation in the flow relative to the pool boiling, respectively. The liquid single-phase convective heat transfer coefficient $h_{l}$ is commonly calculated by the well-known Dittus-Boelter correlation [24]:

$$
h_{l}=0.023 \operatorname{Re}_{l}^{0.8} \operatorname{Pr}_{l}^{0.4} \frac{k_{l}}{D}
$$

where the liquid Reynolds number $\operatorname{Re}_{l}$ and Prandtl number $\operatorname{Pr}_{l}$ are defined as

$$
\begin{gathered}
R e_{l}=\frac{G D(1-x)}{\mu_{l}}, \\
P r_{l}=\frac{\mu_{l} c_{p l}}{k_{l}} .
\end{gathered}
$$

Here $\mu_{l}, c_{p l}$ and $k_{l}$ are the dynamic viscosity, specific heat and thermal conductivity of the liquid phase, respectively, $G$ is the mass flux, $D$ is the tube diameter and $x$ is the vapor quality. Moreover, the calculation methods for the pool boiling heat transfer coefficient $h_{\text {pool }}$ to account for the contribution of nucleate boiling differ greatly among the existing correlations. Two pool boiling 
heat transfer correlations developed by Cooper [25] and Stephan and Abdelsalam [26], respectively, are the most commonly used (which can be concluded from the summary of the existing correlations in Table 2):

$$
\begin{aligned}
& h_{\text {Cooper }}=55 M^{-0.5} q^{-0.67} P_{r}^{0.12}\left(-\log _{10} P_{r}\right)^{-0.55}, \\
& h_{\mathrm{SA}}=207 \frac{k_{l}}{\mathrm{bd}}\left(\frac{q \cdot b d}{k_{l} T_{\mathrm{sat}}}\right)^{0.745}\left(\frac{\rho_{v}}{\rho_{l}}\right)^{0.581} P r_{l}^{0.533},
\end{aligned}
$$

where $M$ is the molecular weight, $T_{\text {sat }}$ is the saturation temperature, $P_{r}$ is the reduced pressure which is obtained as the ratio of the pressure to the critical pressure $P_{c}, \rho_{l}$ and $\rho_{v}$ are the saturated liquid and vapor densities, respectively, and $b d$ is a product of a Laplace constant and the equilibrium break-off-diameter, defined as

$$
b d=0.0146 \beta\left[2 \sigma / g /\left(\rho_{l}-\rho_{v}\right)\right]^{0.5},
$$

where $\sigma$ is the surface tension and the $\beta$ is the contact angle, which is set to $35^{\circ}$ for refrigerants.

In the asymptotic model, the general correlation is defined as

$$
h_{\mathrm{tp}}=\left(h_{\mathrm{cb}}^{\mathrm{n}}+h_{\mathrm{nb}}^{\mathrm{n}}\right)^{1 / \mathrm{n}} n>1 \text {. }
$$

In this approach the value of $h_{t p}$ is primarily governed by the heat transfer coefficient having the largest value $\left(h_{t p}\right.$ or $\left.h_{n b}\right)$, and as $n$ approaches infinity $h_{t p}$ becomes equal to the heat transfer coefficient having the largest value.

In the enhancement model, which was firstly proposed by Shah [27], the general correlation is expressed as

$$
\frac{h_{t p}}{h_{l}}=F,
$$

defining the flow boiling heat transfer coefficient $h_{t p}$ as an enhancement of the liquid single-phase heat transfer coefficient $h_{l}$, where the enhancement factor $F$ is a function of the boiling number $B o$ and the convective number Co. Due to the similarity with the contribution of convective boiling in the superposition model, this model is increasingly employed for modelling the experimental data obtained from the heat transfer region where the convective boiling is dominant, e.g. the Mishra et al. [28] and Shin et al. [29] correlations.

The general method to develop mixture correlations is to modify the pure working fluid correlation by applying two mixture correction factors, $S_{m i x}$ and $F_{m i x}$, to quantify the heat transfer degradation on the contributions of nucleate boiling and convective boiling, respectively. Correspondingly, the mixture correlations for the three described models are modified to the 
following expressions:

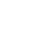

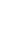

$$
\begin{gathered}
h_{\mathrm{tp}}=S_{\text {mix }} S h_{\text {pool }}+F_{\text {mix }} F h_{l}, \\
h_{\mathrm{tp}}=\left[\left(S_{\text {mix }} S h_{\text {pool }}\right)^{n}+\left(F_{\text {mix }} F h_{\mathrm{l}}\right)^{n}\right]^{1 / n} \\
\frac{h_{t p}}{h_{l}}=F F_{\text {mix }} \text { or } F_{\text {mix }} .
\end{gathered}
$$

\section{Database collection}

A comprehensive literature survey was conducted to collect all the experimental data points within the scope defined in Section 1. For each data point the values of heat transfer coefficient $h$, heat flux $q$, mass flux $G$, composition of the mixture, vapor quality $x$, saturation pressure $P_{\text {sat }}$ or saturation temperature $T_{\text {sat }}$ and diameter of the tube $D$ were collected in order to evaluate the predictive performance of the existing heat transfer correlations and develop the new correlations. The database consists of 2091 data points from 22 independent research groups, which are presented in Table 1. The experimental works include tube diameters ranging from $1.5 \mathrm{~mm}$ to 14 $\mathrm{mm}$ with operation conditions of saturation pressures ranging from $200 \mathrm{kPa}$ to $4156 \mathrm{kPa}$, mass fluxes ranging from $80 \mathrm{~kg} / \mathrm{m}^{2} \mathrm{~s}$ to $1100 \mathrm{~kg} / \mathrm{m}^{2} \mathrm{~s}$, heat fluxes ranging from $1.3 \mathrm{~kW} / \mathrm{m}^{2}$ to $89.6 \mathrm{~kW} / \mathrm{m}^{2}$, and vapor quality ranging from 0.01 to 1 .

Several parameters indicating the features of the mixtures composing the database and their distributions are presented in Figure 2. Different types of organic working fluids were used in the mixtures, including hydrofluorocarbons such as R134a and R32, natural working fluids such as $\mathrm{CO}_{2}$ and propane, and hydrofluoroolefins such as R1234ze and R1234yf. Two pre-defined zeotropic mixtures (i.e. R407C (R32/R125/R134a: 0.23/0.25/0.52) and R417A (R125/R134a/N-butane: $0.466 / 0.5 / 0.034)$ ) were also included. More than half of the working fluid mixtures are binary zeotropic mixtures, while only a small fraction are quaternary mixtures. Moreover, the temperature glide range from $0.004 \mathrm{~K}$ to $89 \mathrm{~K}$ and about half of the data points have a temperature glide within the range $5 \mathrm{~K}$ to $10 \mathrm{~K}$. 


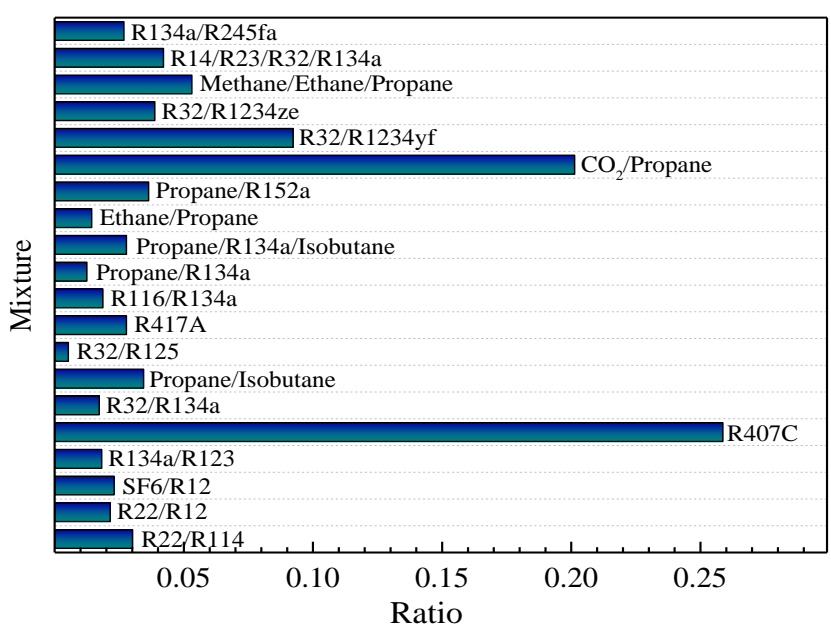

(a)

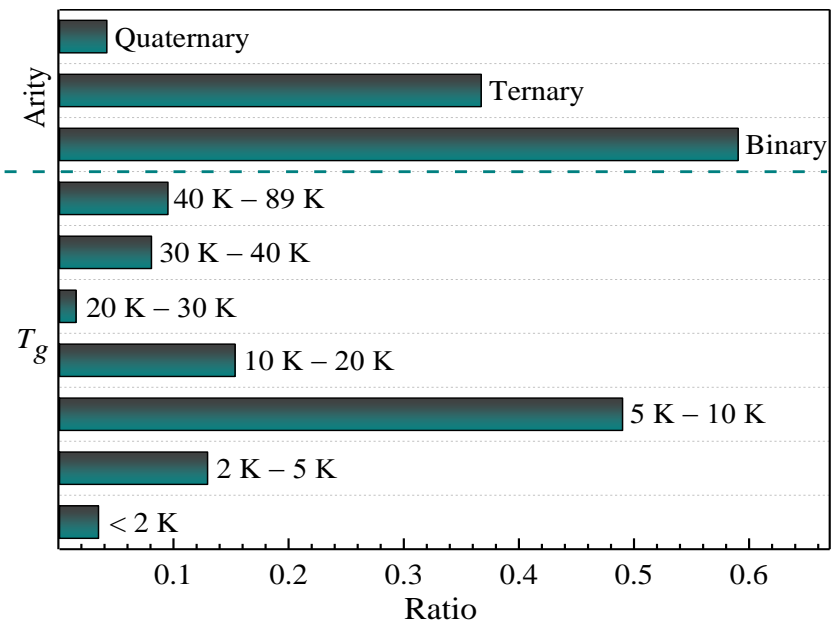

(b)

Figure 2 Distribution of data points related to (a) working fluid mixtures, and (b) number of components and temperature glide of the mixtures.

In this work, the thermodynamic and transport properties of the studied mixtures were calculated by using the software Refprop [30]. For the thermodynamic properties (i.e. density,

8 bubble pressure, dew pressure) a multi-fluid Helmholtz-energy-explicit mixing model was used,

9 weighting the critical properties of the pure-fluid components based on a set of adjustable mixture interaction parameters. These mixture interaction parameters were fitted from experimental data or estimated by the method of Bell and Lemmon [31], if no experimental data were available. In the case of transport properties (i.e. thermal conductivity, dynamic viscosity, and surface tension) extended corresponding states models were used [32-34]. 
1 Table 1 Database of experimental studies on macroscale flow boiling of zeotropic mixture in plain tubes.

\begin{tabular}{|c|c|c|c|c|c|c|c|c|c|c|}
\hline Year & Ref. & Mixture & No. ${ }^{1}$ & Composition & $T_{g}(\mathrm{~K})$ & $G\left(\mathrm{~kg} / \mathrm{m}^{2} \mathrm{~s}\right)$ & $q\left(\mathrm{~kW} / \mathrm{m}^{2}\right)$ & $P_{\text {sat }}(\mathrm{kPa})$ & $x$ & $\begin{array}{c}D \\
(\mathrm{~mm})\end{array}$ \\
\hline \multirow{7}{*}{1989} & \multirow{7}{*}{$\begin{array}{l}\text { Hihara et al. } \\
\text { [21] }\end{array}$} & \multirow{4}{*}{ R22/R114 } & 9 & $0.112 / 0.888$ & 16.3 & 350 & 22 & 320 & \multirow{7}{*}{$\begin{array}{l}0.05 \text { to } \\
0.98\end{array}$} & \multirow{7}{*}{8} \\
\hline & & & 9 & $0.252 / 0.748$ & 19.1 & 340 & 23 & 490 & & \\
\hline & & & 36 & $0.431 / 0.569$ & 16.4 to 16.5 & 191 to 340 & $\begin{array}{c}16.9 \text { to } \\
27.2 \\
\end{array}$ & 596 to 780 & & \\
\hline & & & 9 & $0.669 / 0.331$ & 9.8 & 323 & 22 & 662 & & \\
\hline & & \multirow{3}{*}{$\mathrm{R} 22 / \mathrm{R} 12$} & 9 & $0.152 / 0.848$ & 2.6 & 250 & 21 & 642 & & \\
\hline & & & 9 & $0.518 / 0.482$ & 1.2 & 240 & 21 & 800 & & \\
\hline & & & 27 & $0.323 / 0.677$ & 2.4 & 151 to 305 & $\begin{array}{c}14.3 \text { to } \\
25.8\end{array}$ & 620 to 780 & & \\
\hline 1992 & $\begin{array}{l}\text { Niederkrüer et } \\
\text { al. [35] }\end{array}$ & $\mathrm{SF}_{6} / \mathrm{R} 12$ & 48 & $0.89 / 0.11$ & 5.4 & 80 to 400 & 7 to 67 & 1500 & $\begin{array}{c}0.11 \text { to } \\
0.73\end{array}$ & 14 \\
\hline 1993 & $\begin{array}{c}\text { Murate and } \\
\text { Hashizume } \\
{[36]}\end{array}$ & R134a/R123 & 38 & $0.07 / 0.93$ & 14.9 to 15.0 & 100 to 300 & 10 and 30 & $\begin{array}{l}220 \text { and } \\
240\end{array}$ & $\begin{array}{c}0.14 \text { to } \\
0.98\end{array}$ & 10.7 \\
\hline $\begin{array}{c}1996 \text { and } \\
1997\end{array}$ & $\begin{array}{c}\text { Wang et al. } \\
{[37,38]}\end{array}$ & $\mathrm{R} 407 \mathrm{C}$ & 87 & $0.23 / 0.25 / 0.52$ & 6.0 to 6.1 & 100 to 400 & 2.5 to 20 & $\begin{array}{l}600 \text { and } \\
680\end{array}$ & $\begin{array}{l}0.09 \text { to } \\
0.85\end{array}$ & $\begin{array}{l}7.92 \\
\text { and } \\
6.5\end{array}$ \\
\hline 1997 & $\begin{array}{c}\text { Zhang et al. } \\
\text { [39] }\end{array}$ & $\mathrm{R} 407 \mathrm{C}$ & 13 & $0.23 / 0.25 / 0.52$ & 5.6 & 180 to 370 & 10 & 1038 & $\begin{array}{c}0.15 \text { to } \\
0.71 \\
\end{array}$ & 6 \\
\hline \multirow{7}{*}{1997} & \multirow{7}{*}{ Shin et al. [40] } & \multirow{3}{*}{$\mathrm{R} 32 / \mathrm{R} 134 \mathrm{a}$} & 12 & $0.25 / 0.75$ & 6.0 & \multirow{3}{*}{583} & \multirow{7}{*}{30} & 628 & \multirow{7}{*}{$\begin{array}{c}0.01 \text { to } \\
0.72\end{array}$} & \multirow{7}{*}{7.7} \\
\hline & & & 12 & $0.5 / 0.5$ & 5.5 & & & 831 & & \\
\hline & & & 12 & $0.75 / 0.25$ & 3.1 & & & 1018 & & \\
\hline & & R32/R125 & 11 & $0.5 / 0.5$ & 0.1 & 583 & & 1151 & & \\
\hline & & \multirow{3}{*}{ Propane/Isobutane } & 24 & $0.25 / 0.75$ & 6.5 & \multirow{3}{*}{$\begin{array}{l}424 \text { and } \\
583\end{array}$} & & 309 and 323 & & \\
\hline & & & 24 & $0.5 / 0.5$ & 7.6 & & & 407 and 427 & & \\
\hline & & & 24 & $0.75 / 0.25$ & 5.4 to 5.5 & & & 530 and 545 & & \\
\hline 2000 & $\begin{array}{l}\text { Boissieux et } \\
\text { al. [41] }\end{array}$ & R417A & 30 & $0.466 / 0.5 / 0.034$ & 3.9 to 4.0 & 268.6 & 27 and 42.3 & $\begin{array}{c}452 \text { and } \\
486\end{array}$ & $\begin{array}{c}0.03 \text { to } \\
0.99\end{array}$ & 8.5 \\
\hline \multirow[b]{2}{*}{2000} & \multirow{2}{*}{$\begin{array}{c}\text { Wettermann } \\
\text { and Steiner } \\
\text { [42] }\end{array}$} & \multirow[b]{2}{*}{ R116/R134a } & 24 & $0.288 / 0.712$ & 27.6 & \multirow[b]{2}{*}{80 to 400} & 1.3 to 70.1 & \multirow[b]{2}{*}{1100} & 0.1 & \multirow[b]{2}{*}{14} \\
\hline & & & 15 & $\begin{array}{c}0.123 \text { to } 0.85 / 0.877 \text { to } \\
0.15\end{array}$ & 8.0 to 27.9 & & 1.5 to 69 & & $\begin{array}{c}0.3 \text { to } \\
0.5\end{array}$ & \\
\hline
\end{tabular}




\begin{tabular}{|c|c|c|c|c|c|c|c|c|c|c|}
\hline $\begin{array}{l}2001 \text { and } \\
2003\end{array}$ & $\begin{array}{l}\text { Lallemand et } \\
\text { al. }[43,44]\end{array}$ & $\mathrm{R} 407 \mathrm{C}$ & 182 & $0.23 / 0.25 / 0.52$ & 5.9 & 150 to 300 & 10 and 30 & 770 & $\begin{array}{c}0.05 \text { to } \\
0.97\end{array}$ & $\begin{array}{l}6.5 \\
\text { and } \\
10.7\end{array}$ \\
\hline 2008 & $\begin{array}{l}\text { Rabah and } \\
\text { Kabelac [7] }\end{array}$ & Propane/R134a & 26 & $\begin{array}{c}0.03 \text { to } 0.46 / 0.97 \text { to } \\
0.54 \\
\end{array}$ & 0.004 to 12.9 & 100 to 300 & 16.5 & 200 & 0.2 & 10 \\
\hline \multirow[t]{2}{*}{2008} & \multirow[t]{2}{*}{ Greco [45] } & $\mathrm{R} 407 \mathrm{C}$ & 160 & $0.23 / 0.25 / 0.52$ & 5.6 to 6.4 & $\begin{array}{c}199 \text { to } \\
1100 \\
\end{array}$ & $\begin{array}{l}3.98 \text { to } \\
8.75\end{array}$ & $\begin{array}{c}350 \text { to } \\
1000\end{array}$ & \multirow{2}{*}{$\begin{array}{l}0 \text { to } \\
0.92\end{array}$} & \multirow[t]{2}{*}{6} \\
\hline & & R417A & 28 & $0.466 / 0.5 / 0.034$ & 3.3 to 4.1 & 200 & 8.09 & 380 to 960 & & \\
\hline 2009 & Raja [46] & $\begin{array}{l}\text { Propane/R134a/ } \\
\text { Isobutane }\end{array}$ & 58 & $0.04 / 0.91 / 0.05$ & 6.5 & 32 to 56 & 3.2 to 7.5 & 400 & $\begin{array}{c}0.05 \text { to } \\
0.98\end{array}$ & $\begin{array}{l}9.52 \\
\text { and } \\
12.7\end{array}$ \\
\hline \multirow{2}{*}{2010} & \multirow{2}{*}{$\begin{array}{l}\text { Zou et al. } \\
{[47,48]}\end{array}$} & Ethane/Propane & 30 & $\begin{array}{c}0.18 \text { to } 0.74 / 0.82 \text { to } \\
0.26 \\
\end{array}$ & 13.7 to 19.7 & $\begin{array}{c}63.6 \text { to } \\
102.5 \\
\end{array}$ & $\begin{array}{l}13.1 \text { to } \\
65.5\end{array}$ & 350 to 570 & \multirow{2}{*}{$\begin{array}{c}0.11 \text { to } \\
0.55\end{array}$} & \multirow{2}{*}{8} \\
\hline & & Propane/R152a & 76 & $\begin{array}{c}0.08 \text { to } 0.92 / 0.92 \text { to } \\
0.08 \\
\end{array}$ & 0.01 to 8.2 & $\begin{array}{c}96.2 \text { to } \\
129.4 \\
\end{array}$ & $\begin{array}{l}13.1 \text { to } \\
65.5\end{array}$ & 200 to 400 & & \\
\hline \multirow{3}{*}{2010} & \multirow{3}{*}{ Cho et al.[49] } & \multirow{3}{*}{$\mathrm{CO}_{2} /$ Propane } & 20 & $0.25 / 0.75$ & 34.4 & \multirow{3}{*}{$\begin{array}{l}318 \text { and } \\
656\end{array}$} & \multirow{3}{*}{15 and 30} & 1448 & \multirow{3}{*}{$\begin{array}{c}0.08 \text { to } \\
0.93\end{array}$} & \multirow{3}{*}{4} \\
\hline & & & 20 & $0.5 / 0.5$ & 33.2 & & & 2149.8 & & \\
\hline & & & 20 & $0.75 / 0.25$ & 16.6 & & & 2601.2 & & \\
\hline \multirow{2}{*}{2011} & \multirow{2}{*}{$\begin{array}{c}\text { Grauso et al. } \\
{[9]}\end{array}$} & \multirow{2}{*}{$\mathrm{CO}_{2} /$ Propane } & 94 & $0.7 / 0.3$ & 17.5 to 18.7 & \multirow{2}{*}{200 to 350} & 10 to 20.2 & $\approx 3461$ to & 0.10 to & \multirow{2}{*}{6} \\
\hline & & & 74 & $0.832 / 0.168$ & 6.7 to 7.5 & & 10 & 4156 & 0.99 & \\
\hline \multirow{2}{*}{2012} & \multirow{2}{*}{ Li et al. [50] } & \multirow{2}{*}{ R32/R1234yf } & 115 & $0.2 / 0.8$ & 3.9 to 4.4 & \multirow{2}{*}{100 to 400} & \multirow{2}{*}{6 to 24} & 652 to 683 & \multirow{2}{*}{$\begin{array}{l}0.21 \text { to } \\
1.0\end{array}$} & \multirow{2}{*}{2} \\
\hline & & & 78 & $0.5 / 0.5$ & 5.4 & & & 903 and 910 & & \\
\hline 2013 & $\begin{array}{c}\text { Hossain et al. } \\
\text { [51] }\end{array}$ & R32/R1234ze(E) & 33 & $0.45 / 0.55$ & 8.3 & $\begin{array}{l}200 \text { and } \\
250\end{array}$ & 1.2 to 31.8 & 843 & $\begin{array}{c}0.08 \text { to } \\
1\end{array}$ & 4.35 \\
\hline 2014 & $\begin{array}{c}\text { Kundu et al. } \\
{[52,53]}\end{array}$ & $\mathrm{R} 407 \mathrm{C}$ & 99 & $0.23 / 0.25 / 0.52$ & 5.9 & 100 to 400 & 3 to 10 & $\approx 710$ & $\begin{array}{c}0.12 \text { to } \\
0.89\end{array}$ & 7 \\
\hline 2015 & Qiu et al. [54] & R32/R1234ze(E) & 48 & $0.73 / 0.27$ & 3.2 & 200 to 400 & 5 and 10 & $\approx 1000$ & $\begin{array}{c}0.1 \text { to } \\
0.83\end{array}$ & 8 \\
\hline \multirow{3}{*}{2015} & \multirow{3}{*}{ Zhu et al. [55] } & \multirow{3}{*}{$\mathrm{CO}_{2} /$ Propane } & 64 & $0.75 / 0.25$ & 14.0 to 15.9 & \multirow{3}{*}{200 to 400} & \multirow{3}{*}{5 to 15} & \multirow{3}{*}{$\begin{array}{l}\approx 1622 \text { to } \\
3758\end{array}$} & & \\
\hline & & & 65 & $0.5 / 0.5$ & 31.0 to 32.6 & & & & 0.1 to & 2 \\
\hline & & & 64 & $0.25 / 0.75$ & 32.6 to 33.9 & & & & & \\
\hline 2016 & Barraza et al. & $\begin{array}{l}\text { Methane/Ethane/ } \\
\text { Propane }\end{array}$ & 111 & $0.27 / 0.40 / 0.33$ & 85.6 and 86 & 138 to 242 & 27.8 to & 265 to 791 & 0.04 to & 1.5 \\
\hline 2010 & {$[56]$} & R12/R23/R32/R134a & 88 & $\begin{array}{c}0.363 / 0.124 / 0.093 / 0.4 \\
20\end{array}$ & 88.7 to 89.1 & 158 to 242 & 89.6 & 205 to /91 & 0.93 & and 3 \\
\hline
\end{tabular}




\begin{tabular}{|c|c|c|c|c|c|c|c|c|c|c|}
\hline 2016 & Guo et al. [57] & $\mathrm{R} 134 \mathrm{a} / \mathrm{R} 245 \mathrm{fa}$ & 56 & $0.82 / 0.18$ & 5.5 to 6.1 & 280 to 469 & 15 to 43 & 540 to 840 & $\begin{array}{c}0.23 \text { to } \\
0.84\end{array}$ & 3 \\
\hline
\end{tabular}

\footnotetext{
$1{ }^{1}$ Number of experimental data points.
} 


\section{Evaluation of existing correlations}

Fifteen existing correlations for mixture flow boiling were selected in this study to assess their predictive performance for the collected experimental data points. The correlations selected are not only widely used in the open literature, but also easily applied in practice. Two classical correlations by Chen and Bennett [58] and Kandlikar [59] were excluded from this evaluation due to their use of the mass diffusivity, which is difficult to obtain $[6,60]$.

The correlations were classified into two categories: specific and general. In the former category, the correlations were developed based on specific data sets (usually the data points from the researchers' own experiments), i.e. some or all of the coefficients $F, S, F_{m i x}$ and $S_{\text {mix }}$ were derived using multiple regression with the specific data. The specific correlations are summarized in Table 2.

Table 2 Specific correlations for mixture flow boiling heat transfer.

\begin{tabular}{|c|c|c|c|c|}
\hline Year & Reference & Model & Correlation & Details \\
\hline 1981 & $\begin{array}{l}\text { Mishra et } \\
\text { al. [28] }\end{array}$ & EM & $\begin{array}{l}\frac{h_{\mathrm{tp}}}{h_{l}}=21.75\left(\frac{1}{X_{t t}}\right)^{0.29} B o^{0.23} ; \\
\text { Martinelli number } X_{t t} \text { and boiling } \\
\text { number } B o \text { are defined as } \\
X_{t t}=\left(\frac{\rho_{v}}{\rho_{l}}\right)^{0.5}\left(\frac{\mu_{l}}{\mu_{v}}\right)^{0.1}\left(\frac{1-x}{x}\right)^{0.9}, \\
B o=\frac{q}{G h_{\mathrm{fg}}} .\end{array}$ & $\begin{array}{l}\text { - The correlation was developed } \\
\text { with multiple regression analysis } \\
\text { based on the experimental results } \\
\text { of R12/R22 mixtures in the } \\
\text { annular flow. }\end{array}$ \\
\hline 1989 & $\begin{array}{l}\text { Jung et al. } \\
\text { [6] }\end{array}$ & SM & $\begin{array}{l}h_{\mathrm{tp}}=\frac{S}{C_{\mathrm{UN}}} h_{\mathrm{UN}}+C_{\mathrm{me}} F h_{l} ; \\
\text { two mixture correction factors } C_{\mathrm{UN}} \text { and } \\
C_{\mathrm{me}} \text { for the contributions of nucleate } \\
\text { and convective boiling are defined as } \\
C_{U N}=\left[1+\left(b_{2}+b_{3}\right)\left(1+b_{4}\right)\right](1+ \\
\left.b_{5}\right) ; \\
b_{2}=\left(1-\tilde{x}_{1}\right) \ln \left(\frac{1.01-\tilde{x}_{1}}{1.01-\tilde{y}_{1}}\right)+\tilde{x}_{1} \ln \left(\frac{\tilde{x}_{1}}{\tilde{y}_{1}}\right) ; \\
b_{3}=0 \text { for } \tilde{x}_{1} \geq 0.01 ; \\
b_{3}=\left(\tilde{y}_{1} / \tilde{x}_{1}\right)^{0.1}-1 \text { for } \tilde{x}_{1} \geq 0.01 ; \\
b_{4}=152\left(P / P_{\mathrm{c}, 1}\right)^{3.9} ; \\
b_{5}=0.92\left|\tilde{y}_{1} / \tilde{x}_{1}\right|^{0.001}\left(P / P_{c, 1}\right)^{0.66} ; \\
\tilde{x}_{1} / \tilde{y}_{1}=1 \text { for } \tilde{x}_{1}=\tilde{y}_{1}=0 ; \\
C_{\mathrm{me}}=1-0.35\left|\tilde{y}_{1}-\tilde{x}_{1}\right|^{1.56} ; \\
\text { the nucleate pool boiling heat transfer } \\
\text { coefficient of a mixture } h_{\mathrm{UN}} \text { and the } \\
\text { ideal heat transfer coefficient } h_{i d} \text { are } \\
\text { expressed as } \\
h_{\mathrm{UN}}=h_{i d} / C_{\mathrm{UN}} ; h_{i d}=1 / \sum_{i=1}^{n} \tilde{x}_{i} / h_{i} ; \\
\text { the nucleate pool boiling heat transfer } \\
\text { coefficient for each pure working fluid } \\
h_{i} \text { was calculated as } \\
h_{\mathrm{i}}=h_{S A} ; \\
F=2.37\left(0.29+\frac{1}{X_{t t}}\right)^{0.85} ;\end{array}$ & $\begin{array}{l}\text { - The correlation was developed } \\
\text { based on local data of heat } \\
\text { transfer coefficients from the } \\
\text { R22/R114 and R12/R152a } \\
\text { mixtures. } \\
\text { - The enhancement factor } F \text { and } \\
\text { suppression factor } S \text { were } \\
\text { derived through a regression } \\
\text { analysis of the experimental data } \\
\text { with pure working fluids. } \\
\text { - The mixture correction factor for } \\
\text { nucleate boiling } C_{U N} \text { was } \\
\text { developed by Ünal [61], and } \\
\text { another mixture correction factor } \\
C_{m e}, \text { was obtained by using only } \\
\text { the phase equilibrium data }\left(\tilde{y}_{1}-\right. \\
\left.\tilde{x}_{1}\right) \text { in order to take account for } \\
\text { the mass transfer resistance } \\
\text { effects on convective } \\
\text { evaporation. }\end{array}$ \\
\hline
\end{tabular}




\begin{tabular}{|c|c|c|c|c|}
\hline & & & $S=4048 X_{t t}{ }^{0.85} B o^{1.13}$ & \\
\hline 1991 & $\begin{array}{l}\text { Granryd } \\
{[62]}\end{array}$ & EM & $\begin{array}{l}\frac{h_{\mathrm{tp}}}{h_{l}}=\frac{F}{1+A} ; \\
F=2.37\left(0.29+\frac{1}{X_{t t}}\right)^{0.85} ; \\
\text { the mixture correction factor A is } \\
\text { defined as } \\
A=\left(\frac{F}{C_{\mathrm{lg}}}\right) x^{2}\left[\left(\frac{1-x}{x}\right)\left(\frac{\mu_{v}}{\mu_{l}}\right)\right]^{0.8} \\
\left(\frac{\operatorname{Pr}_{l}}{\mathrm{Pr}_{v}}\right)^{0.4}\left(\frac{k_{v}}{k_{l}}\right)\left(\frac{c_{p v}}{c_{p w}}\right) ; C_{\mathrm{lg}}=2 ; \\
\text { an 'apparent local specific heat' } c_{p w} \text { for } \\
\text { mixture in the two-phase region at } x \text { is } \\
\text { defined as } \\
c_{p w}=\left(\frac{\partial H}{\partial T}\right)_{p} .\end{array}$ & $\begin{array}{l}\text { - The correlation was developed } \\
\text { based on the assumption that gas } \\
\text { phase resistance is similar to that } \\
\text { introduced in the Silver-Bell- } \\
\text { Ghaly method [63] and was } \\
\text { validated using data reported in } \\
\text { Jung et al. [20] data for the } \\
\text { mixtures R12/R125 and } \\
\text { R22/R114. } \\
\text { - The enhancement factor } F \text { is the } \\
\text { same as the one used in the } \\
\text { correlation presented by Jung et } \\
\text { al. [6]. }\end{array}$ \\
\hline 1993 & $\begin{array}{l}\text { Takamatsu } \\
\text { et al. [64] }\end{array}$ & SM & 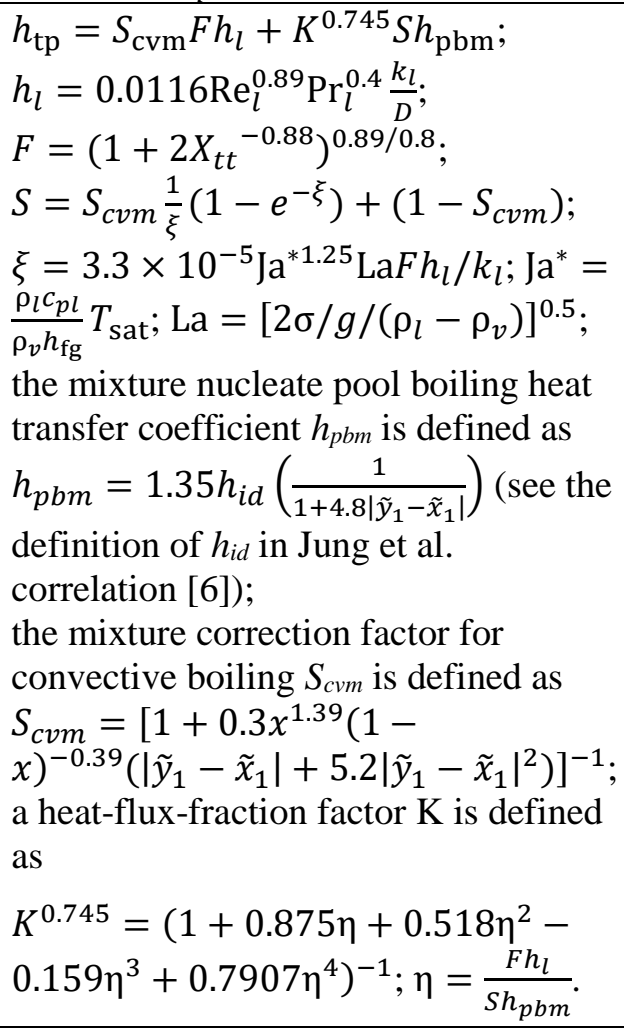 & $\begin{array}{l}\text { - The correlation was derived } \\
\text { based on the test data of } \\
\text { R22/R114 and was validated } \\
\text { with the experimental results } \\
\text { obtained by Jung and Didion } \\
\text { [65]. } \\
\text { - The enhancement factor } F \text { and } \\
\text { liquid single-phase convective } \\
\text { heat transfer coefficient } h_{l} \text { was } \\
\text { obtained with multiple } \\
\text { regression in the authors' } \\
\text { previous work for pure working } \\
\text { fluids [66]. } \\
\text { - The factor } K \text {, which indicates the } \\
\text { ratio of heat flux for the nucleate } \\
\text { boiling region to the whole } \\
\text { boiling region, was developed to } \\
\text { modify the suppression of } \\
\text { nucleate boiling with respect to } \\
\text { the pool boiling. } \\
\text { - } S_{c v m} \text { was obtained using the least } \\
\text { squares method with mixture test } \\
\text { data. }\end{array}$ \\
\hline 1994 & $\begin{array}{l}\text { Bivens and } \\
\text { Yokozeki } \\
{[67]}\end{array}$ & $\begin{array}{l}\text { EM- } \\
\text { AM }\end{array}$ & $\begin{array}{l}\frac{h_{t p}}{h_{i d}}=\frac{1}{1+h_{i d} T_{\mathrm{int}} / q} ; \\
h_{\text {id }} \text { is calculated using a correlation for } \\
\text { pure working fluids using transport } \\
\text { properties of the mixture: } \\
h_{i d}=\left(h_{\mathrm{cb}}^{2.5}+h_{\mathrm{nb}}^{2.5}\right)^{1 / 2.5} ; \\
h_{n b}=h_{\text {Cooper }} ; \\
h_{\mathrm{cb}}=2.15 h_{l}\left(0.29+1 / X_{t t}\right)^{0.85} \text { for } \\
\mathrm{Fr}_{l} \geq 0.25 ; \\
h_{\mathrm{cb}}=2.838 h_{l}\left(0.29+1 / X_{t t}\right)^{0.85} \mathrm{Fr}_{l}^{0.2} \\
\text { for } \mathrm{Fr}_{l} \leq 0.25 ; \\
F r_{l}=\frac{G^{2}}{\mathrm{gD}_{l}} ; \\
\text { the correction factor is defined as } \\
\text { follows: } \\
T_{\text {int }}=0.175\left(T_{d}-T_{b}\right)[1-\end{array}$ & $\begin{array}{l}\text { - The correlation used to calculate } \\
\text { the ideal heat transfer coefficient } \\
h_{i d} \text { was developed with a } \\
\text { modification on the correlations } \\
\text { presented by Jung et al. [6] and } \\
\text { Wattelet et al. [68]. }\end{array}$ \\
\hline
\end{tabular}




\begin{tabular}{|c|c|c|c|c|}
\hline & & & $\left.\exp \left(\frac{q}{1.3 \times 10 \rho_{l} h_{f g}}\right)\right]$ & \\
\hline 1996 & $\begin{array}{l}\text { Shin et al. } \\
\text { [29] }\end{array}$ & EM & 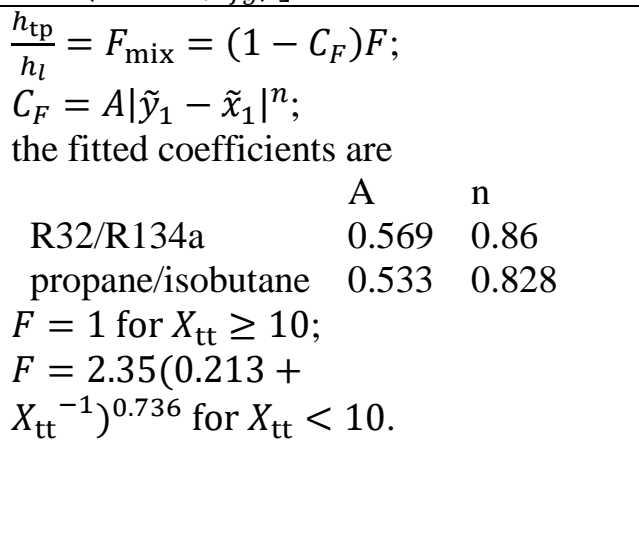 & $\begin{array}{l}\text { - The correlation was developed } \\
\text { based on the test data of } \\
\text { R32/R134a and } \\
\text { propane/isobutane in the annular } \\
\text { flow. } \\
\text { - The mixture enhancement } F_{m i x} \\
\text { was developed based on Chen's } \\
F \text { factor [23] and by introducing } \\
\text { a curve-fitted correction factor } \\
C_{F} \text { for the mixture heat transfer } \\
\text { degradation due to the mass } \\
\text { transfer resistance. }\end{array}$ \\
\hline 2000 & $\begin{array}{l}\text { Choi et al. } \\
{[69]}\end{array}$ & SM & $\begin{array}{l}h_{\mathrm{tp}}=S h_{\text {pool }}+F_{\mathrm{mix}} F h_{l} ; \\
h_{\text {pool }}=h_{\mathrm{SA}} ; \\
F=49.971 X_{t t}{ }^{-0.758} \mathrm{Bo}^{0.383} ; \\
S=0.909\left[\left(\frac{1-x}{x}\right)\left(\frac{\rho_{l}}{\rho_{v}}\right)\right]^{0.5} ; \\
F_{\text {mix }}=\frac{1}{1+0.039\left[c_{p l}\left(T_{d}-T_{b}\right) / h_{\mathrm{fg}}\right]} .\end{array}$ & $\begin{array}{l}\text { - The correlation was developed } \\
\text { based on the experimental data } \\
\text { of the mixtures R32/R134a and } \\
\text { R407C. } \\
\text { - } F \text { and } S \text { were developed using an } \\
\text { iterative process to minimize the } \\
\text { error between the predicted and } \\
\text { experimental results using the } \\
\text { test data of the pure working } \\
\text { fluids R32 and R134a. } \\
\text { - } F_{m i x} \text { was modified by simplifying } \\
\text { the effect of heat flux in the } \\
\text { model by Thome and Shakir [70] } \\
\text { considering that the heat flux has } \\
\text { been taken account for by } h_{S A} \\
\text { and } B o \text {. }\end{array}$ \\
\hline 2009 & $\begin{array}{l}\text { Chiou et } \\
\text { al. [8] }\end{array}$ & EM & $\begin{array}{l}\frac{h_{\mathrm{tp}}}{h_{\mathrm{tp}, \mathrm{id}}}=\frac{1}{1+\frac{T_{\mathrm{g}}}{\Delta T_{\mathrm{id}}}(\mathrm{PF}) f n\left(q, P_{r}\right)}=F_{\mathrm{mix}} ; \\
\text { the mixture ideal heat transfer } \\
\text { coefficient } h_{\mathrm{tp}, \mathrm{id}} \text { is defined as } \\
h_{\mathrm{tp}, \mathrm{id}}=\left(\sum_{i=1}^{n} \frac{X_{i}}{h_{\mathrm{tp}, \mathrm{p}}}\right)^{-1} ; \\
\text { the flow boiling heat transfer coefficient } \\
\text { of pure working fluid } h_{\mathrm{tp}, \mathrm{p}}: \\
\ln \left(\frac{h_{t p, p}}{h_{l}}\right)=-1.71+0.77 \ln \left(\frac{M}{X_{\mathrm{tt}}}\right) ; \\
\Delta T_{\mathrm{id}}=q / h_{\mathrm{tp}, \mathrm{id}} ; \\
\mathrm{PF}=\left(\frac{\rho_{v}}{\rho_{l}}\right)\left(\frac{k_{l} \mu_{l} M}{\rho_{l} c_{p l} T_{b}}\right)^{0.5} ; f n\left(q, P_{r}\right)= \\
\left(1.5 \times 10^{-5} \frac{q}{P_{r}}+\frac{75}{\Delta T_{0}}\right) \times 10^{6} ; \\
\Delta T_{0}=T_{\mathrm{g}} \text { for } T_{\mathrm{g}}>5 ; \Delta T_{0}=5 \text { for } T_{\mathrm{g}} \leq \\
5 .\end{array}$ & $\begin{array}{l}\text { - The correlation was developed } \\
\text { based on the experimental data } \\
\text { of the mixture R22/R124. } \\
\text { - The correlation used to calculate } \\
h_{t p, p} \text { was modified based on the } \\
\text { model by Wadelar [71] by only } \\
\text { considering the convective flow } \\
\text { boiling contribution. } \\
\text { - } F_{m i x} \text { was modified from the one } \\
\text { derived by experimental data of } \\
\text { mixture pool boiling in the } \\
\text { authors' previous work [72]. }\end{array}$ \\
\hline 2010 & $\begin{array}{l}\text { Zou et al. } \\
{[48]}\end{array}$ & AM & $\begin{array}{l}h_{\mathrm{tp}}=\left[\left(F h_{l}\right)^{2}+\left(S_{\text {mix }} S h_{\text {pool }}\right)^{2}\right]^{0.5} ; \\
h_{\text {pool }}=h_{\text {Cooper }} \\
F=\left[1+x P r_{l}\left(\rho_{l} / \rho_{v}-1\right)\right]^{0.35} \\
S=\left(1+0.055 F^{0.1} \operatorname{Re}_{l}^{0.16}\right)^{-1} \\
S_{\text {mix }}= \\
\frac{1}{1+\frac{\Delta T_{\mathrm{db}}}{\Delta T_{\mathrm{id}}}\left|\tilde{y}_{1}-\tilde{x}_{1}\right|^{-0.29}\left(\frac{P}{10^{5}}\right)^{-0.9}\left[1-0.87 \exp \left(-\frac{q}{3 \times 10^{5}}\right)\right]}\end{array}$ & $\begin{array}{l}\text { - The correlation was developed } \\
\text { with a modification of the pure } \\
\text { working fluid flow boiling } \\
\text { correlation by Liu and Winterton } \\
\text { [73] by adding a mixture } \\
\text { correction factor } S_{m i x} \text { in the } \\
\text { nucleate boiling contribution } \\
\text { (see the difference between the }\end{array}$ \\
\hline
\end{tabular}




\begin{tabular}{|c|c|c|c|c|}
\hline & & & $\begin{array}{l}\Delta T_{\mathrm{db}}=T_{d}-T_{b} ; \Delta T_{\mathrm{id}}=q / h_{\mathrm{id}} ; h_{i d}= \\
1 / \sum_{i=1}^{n} \tilde{x}_{i} / h_{i} ; \\
\text { the flow boiling heat transfer coefficient } \\
\text { of each pure working fluid } h_{i} \text { was } \\
\text { calculated by the correlation presented } \\
\text { by Liu and Winterton [73]: } \\
h_{\mathrm{tp}, \mathrm{p}}=\left[\left(F h_{l}\right)^{2}+\left(S h_{\mathrm{nb}}\right)^{2}\right]^{0.5} .\end{array}$ & $\begin{array}{l}\text { correlations of } \mathrm{h}_{t p} \text { and } \mathrm{h}_{t p, p} \text { ). } \\
S_{m i x} \text { was developed by an } \\
\text { iteration process to minimize the } \\
\text { error between predicted and } \\
\text { experimental results using the } \\
\text { test data of the mixture } \\
\text { consisting of ethane/propane. }\end{array}$ \\
\hline 2016 & $\begin{array}{l}\text { Guo et al. } \\
\text { [57] }\end{array}$ & $\mathrm{AM}$ & $\begin{array}{l}h_{\mathrm{tp}}=\left[\left(F h_{l}\right)^{2}+\left(S h_{\text {pool }}\right)^{2}\right]^{0.5} \\
h_{n b}=h_{\text {Cooper }} \\
F=\left[1+0.063 x \operatorname{Pr}_{l}^{-0.69}\left(\rho_{l} / \rho_{v}-\right.\right. \\
1)]^{4.4} ; \\
S=\left(1-0.084 F^{0.17} \mathrm{Re}_{l}^{0.39}\right)^{-1}\end{array}$ & $\begin{array}{l}\text { - The correlation was obtained by } \\
\text { modifying the model presented } \\
\text { by Liu and Winterton [73] by } \\
\text { refitting the coefficients } F \text { and } S \\
\text { based on their experimental } \\
\text { results of the mixture consisting } \\
\text { of R134a/R245fa. }\end{array}$ \\
\hline
\end{tabular}

The second category of correlations, defined as the general correlations in this study, were developed by modifying the pure working fluid correlations. The idea is to apply a general correction approach to any well-verified pure working fluid correlation, quantifying the heat transfer degradation caused by the mixture effect with respect to the pure-fluid components. Such method aims to widen the application range of the correlation, independent of the experimental data. Particularly, two well-known research efforts were made by Thome [18] and Shah [10], respectively, to propose such modification method. The method proposed by Thome [18] suggests modifying the base pure working fluid correlation by i) using local mixture properties to include the effect of nonlinear variation in mixture physical properties, and ii) employing a mixture correction factor $F_{c}$ to the nucleate boiling contribution to include the mixture mass diffusion effect. This mixture correction factor $F_{c}$ was developed by modelling analytically the mass transfer resistance on nucleate pool boiling in plain tubes and is defined as

$$
F_{c}=\left\{1+\left(\frac{h_{i d}}{q}\right)\left(T_{d}-T_{b}\right)\left[1-\exp \left(-\frac{B q}{\rho_{l} h_{\mathrm{fg}} \beta_{l}}\right)\right]\right\}^{-1},
$$

where $h_{i d}$ is the ideal heat transfer coefficient calculated with Cooper's correlation (see Eq. (6)), and $B$ is the scaling factor assumed to be 1.0, i.e. assuming that all the heat transferred to the bubble interface is converted to latent heat. The liquid-phase mass transfer $\beta_{l}$ was assumed to be $0.0003 \mathrm{~m} / \mathrm{s}$. It has been demonstrated that this value provides the best predictive performance for mixture flow boiling [74]. Following the same correction approach for the nucleate boiling contribution, Shah [10] modified further the convective boiling contribution of the pure working fluid $h_{c b}$ by using the Bell-Ghaly correction factor [75], and the modified mixture heat transfer coefficient for convective boiling contribution $h_{c b, m i x}$ can be calculated by

$$
\frac{1}{h_{c b, m i x}}=\frac{1}{h_{c b}}+\frac{Y}{h_{v}}
$$


2 Here $c_{p v}$ is the specific heat of the vapor phase and $H$ is the enthalpy of the mixture, and the vapor 3 single-phase convective heat transfer coefficient $h_{v}$ is calculated by the Dittus-Boelter correlation 4 [24]:

$$
h_{v}=0.023 \operatorname{Re}_{v}^{0.8} \operatorname{Pr}_{v}^{0.4} \frac{k_{v}}{D} \text {, }
$$

where the vapor Reynolds number $R e_{v}$ and Prandtl number $P r_{v}$ are defined as

$$
R e_{v}=\frac{G D x}{\mu_{v}},
$$

and

$$
P r_{v}=\frac{\mu_{l} c_{p v}}{k_{v}}
$$

Here $\mu_{v}$ and $k_{v}$ are dynamic viscosity and thermal conductivity of the vapor phase, respectively. Finally, using Shah's method, a pure working fluid correlation with the form of Eq. (1) is modified as follows:

$$
h_{t p}=F_{c} h_{n b}+\left(\frac{1}{h_{c b}}+\frac{Y}{h_{v}}\right) .
$$

Two base pure working fluid correlations developed by Gungor and Winterton [76] in 1986 (GW86) Gungor and Winterton [77] in 1987 (GW87), respectively, were suggested by Thome [18] following the modification method. In addition, three base pure working fluid correlations developed by Shah [78], Gungor and Winterton [77] and Liu and Winterton [73] (LW), respectively, were employed in the modification method by Shah [10], demonstrating good predictive

\begin{tabular}{|c|c|c|c|}
\hline Name & Model & Pure working fluid correlation & Modified mixture correlation \\
\hline $\begin{array}{l}\text { Thome- } \\
\text { GW86 }\end{array}$ & SM & $\begin{array}{l}h_{t p}=S h_{\text {pool }}+F h_{l} \\
F=1+24000 B o^{1.16} X_{\mathrm{tt}}^{-0.86} \\
S=\left(1+1.15 \times 10^{-6} F^{2} R_{l}^{1.17}\right)^{-1} \\
h_{\text {pool }}=h_{\text {Cooper }}\end{array}$ & $h_{t p}=S h_{p o o l}+F_{c} F h_{l}$ \\
\hline $\begin{array}{l}\text { Thome- } \\
\text { GW87 }\end{array}$ & EM & $\begin{array}{l}\frac{h_{\mathrm{tp}}}{h_{l}}=F \\
F=1+3000 B o^{0.86}+1.12\left(\frac{x}{1-x}\right)^{0.75}\left(\frac{\rho_{l}}{\rho_{v}}\right)^{0.41} .\end{array}$ & $\begin{array}{l}\frac{h_{\text {tp }}}{h_{l}}=F_{\text {mix }} \\
F_{\text {mix }}=1+3000\left(B o F_{c}\right)^{0.86}+ \\
1.12\left(\frac{x}{1-x}\right)^{0.75}\left(\frac{\rho_{l}}{\rho_{v}}\right)^{0.41}\end{array}$ \\
\hline $\begin{array}{l}\text { Shah- } \\
\text { Shah }\end{array}$ & EM & $\begin{array}{l}\frac{h_{\mathrm{tp}}}{h_{l}}=F \\
C o=\left(\frac{\rho_{v}}{\rho_{l}}\right)^{0.5}\left(\frac{1-x}{x}\right)^{0.8} ; F r_{l}=\frac{G^{2}}{\mathrm{gD} \rho_{l}^{2}}\end{array}$ & $\begin{array}{l}\text { As stated by Shah [10], the } \\
\text { mixture heat transfer coefficient } \\
\text { is the highest of } h_{n b, m i x}, h_{c b, m i x} \text { and } \\
h_{b s, m i x} \text {, calculated by the three }\end{array}$ \\
\hline
\end{tabular}
performance with the database collected by Shah [10]. The aforementioned five general correlations were selected in this study; see Table 3.

Table 3 General correlations for mixture flow boiling heat transfer. 


\begin{tabular}{|c|c|c|c|}
\hline & & $\begin{array}{l}\text { For } F r_{l} \geq 0.04, N=C o \\
\text { For } F r_{l} \leq 0.04, N=0.38 \mathrm{CoFr}_{l}^{-0.3} \\
\text { For } B o \geq 11 \times 10^{-4},=14.7 \\
\text { For } B o<11 \times 10^{-4} ; F=15.43 \\
\text { For } N>1 \\
F_{n b}=230 B o^{0.5}, B o>0.3 \times 10^{-4} \\
F_{n b}=1+46 B o^{0.5}, B o<0.3 \times 10^{-4} \\
\text { For } 0.1<N \leq 1 \\
F_{b s}=F B o^{0.5} \exp \left(2.74 N^{-0.1}\right) \\
\text { For } N \leq 0.1 \\
F_{b s}=F B o^{0.5} \exp \left(2.47 N^{-0.15}\right) \\
F_{c b}=1.8 / N^{0.8} \\
F=\max \left(F_{c b}, F_{n b} / F_{b s}\right)\end{array}$ & $\begin{array}{l}\text { following equations: } \\
h_{n b, \text { mix }}=F_{c} h_{l} F_{n b} ; \\
h_{c b, \text { mix }}=\left(1 / F_{c b} h_{l}+Y / h_{v}\right)^{-1} ; \\
h_{b s, \text { mix }}=\left[\left(h_{b s}-h_{n b, \text { mix }}\right)^{-1}+\right. \\
\left.Y / h_{v}\right]^{-1}, \text { where the } h_{b s} \text { is defined } \\
\text { as } \\
h_{b s}=F_{c} h_{l} F_{b s} .\end{array}$ \\
\hline $\begin{array}{l}\text { Shah- } \\
\text { GW87 }\end{array}$ & EM & See the Thome-GW87 correlation. & $h_{t p}=\left(1 / F h_{l}+Y / h_{v}\right)^{-1}$ \\
\hline $\begin{array}{l}\text { Shah- } \\
\text { LW }\end{array}$ & $\mathrm{AM}$ & $\begin{array}{l}h_{\mathrm{tp}}=\left[\left(F h_{l}\right)^{2}+\left(S h_{\text {pool }}\right)^{2}\right]^{0.5} \text { (see } F, S \text { and } h_{\text {pool }} \text { in } \\
\text { the correlation by Zou et al. [48]. }\end{array}$ & $\begin{array}{l}h_{\text {tp }}=\left[\left(1 / F h_{l}+Y / h_{v}\right)^{-2}+\right. \\
\left.\left(F_{c} S h_{\text {pool }}\right)^{2}\right]^{0.5}\end{array}$ \\
\hline
\end{tabular}

1

Four parameters were used to evaluate the predictive performance of the correlations presented in Tables 2 and 3. Among them, the mean absolute percentage deviation (MAPD) and the mean bias percentage deviation (MBPD), aiming at quantifying the deviations between the predicted results and the experimental data from the database, are defined as

$$
M A P D=\frac{1}{n} \sum_{i=1}^{n}\left|\frac{h_{i, p r e d}-h_{i, \text { exp }}}{h_{i, \text { exp }}}\right| \times 100 \%
$$

and

$$
M B P D=\frac{1}{n} \sum_{i=1}^{n}\left(\frac{h_{i, p r e d}-h_{i, e x p}}{h_{i, \exp }}\right) \times 100 \%,
$$

where $h_{i, p r e d}$ and $h_{i, \text { exp }}$ are the predicted heat transfer coefficient calculated by the correlations and the experimental heat transfer coefficient, respectively. The MAPD indicates the average deviation between the predicted and experimental values, while the MBPD indicates whether the predicted values, on average, represent an overestimation (positive value) or underestimation (negative value) of the experimental values. In addition, two parameters were used, PCT30 and PCT50, indicating the percentage of the data points within a percentage deviation of $\pm 30 \%$ and $\pm 50 \%$, respectively. 


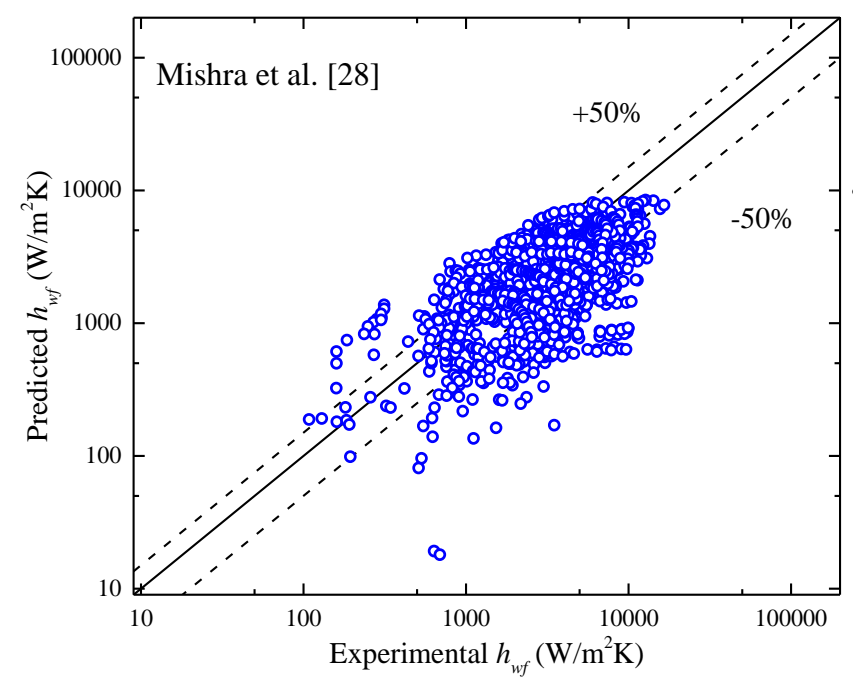

(a)

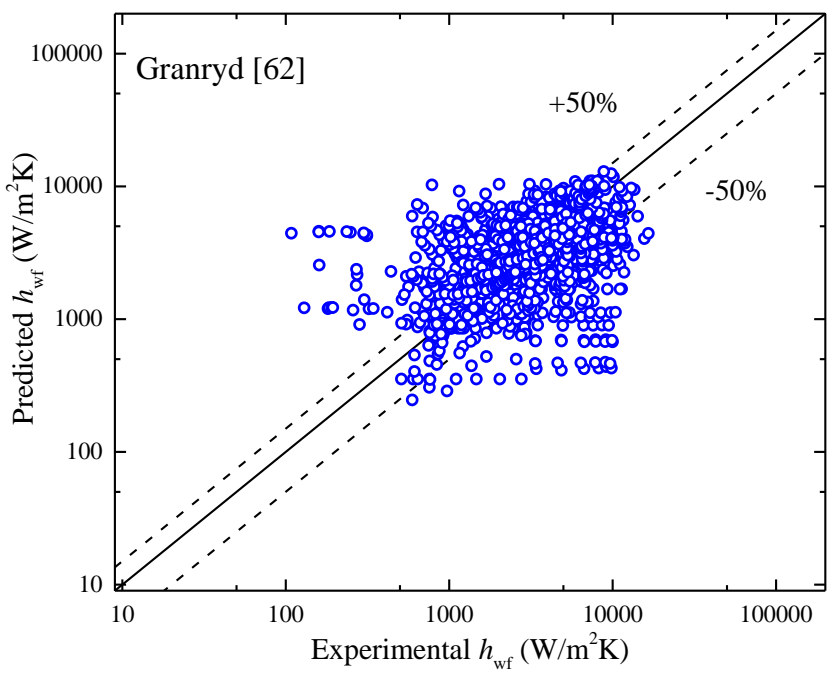

(c)

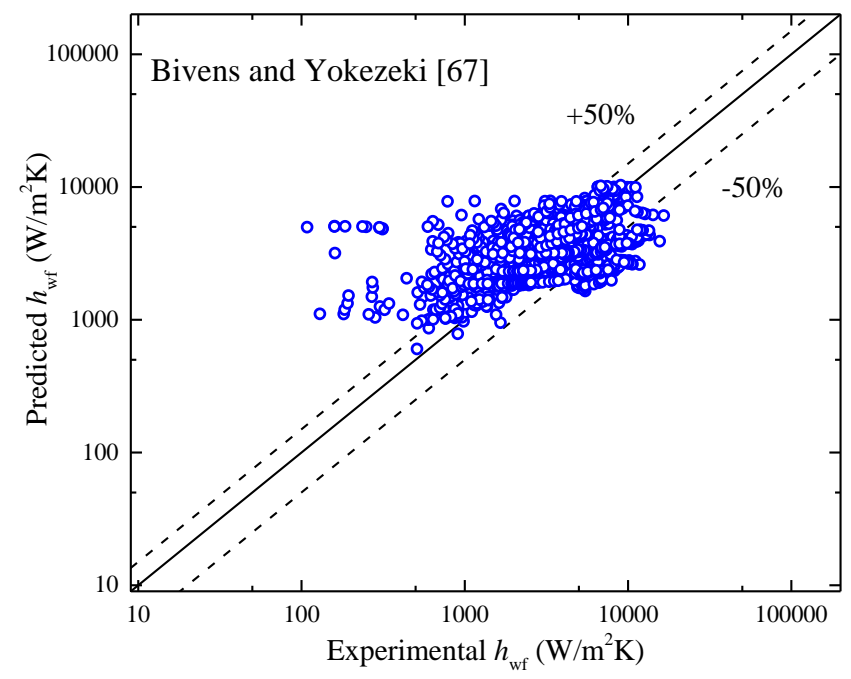

6

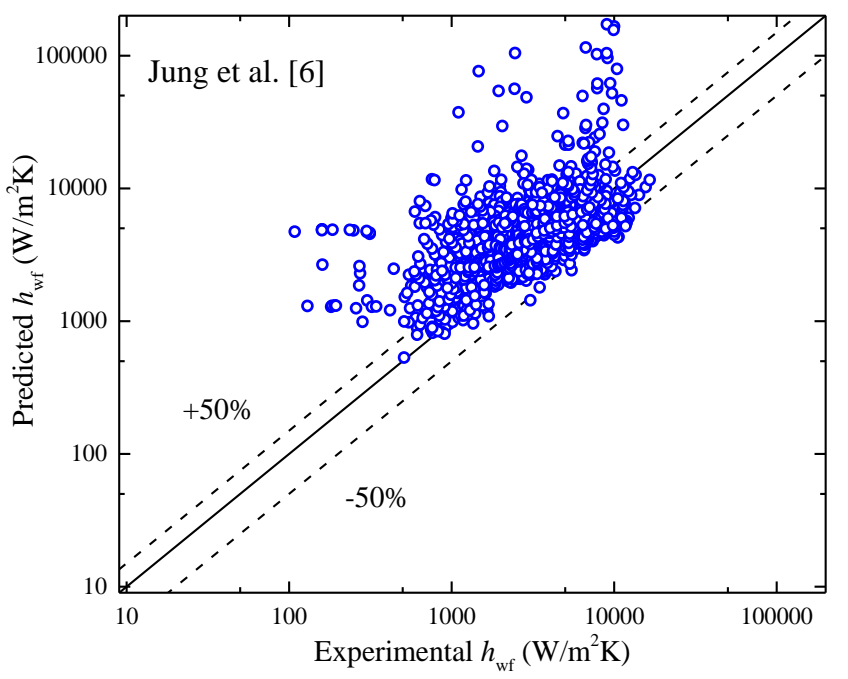

(b)

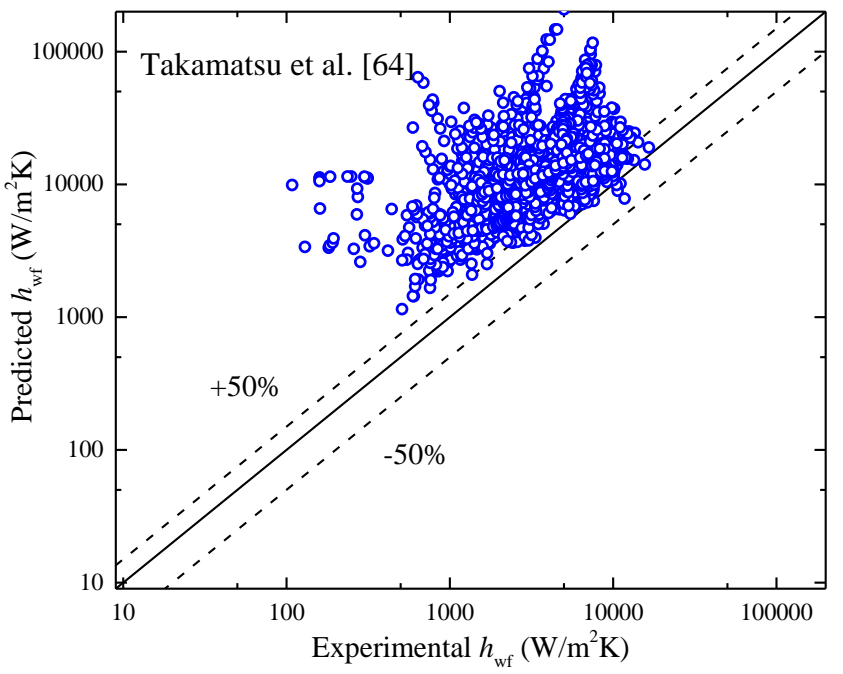

(d)

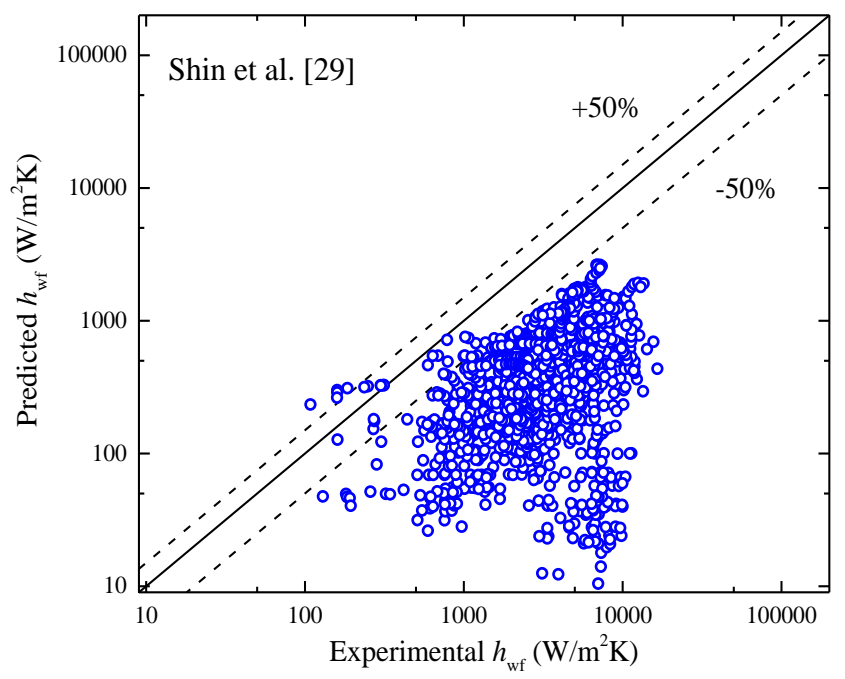

(f) 


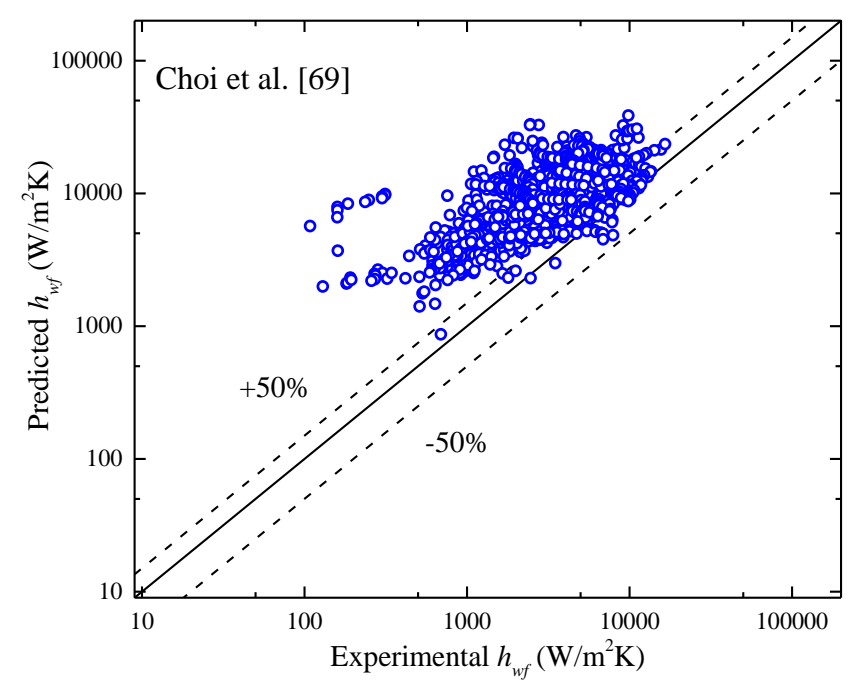

(g)

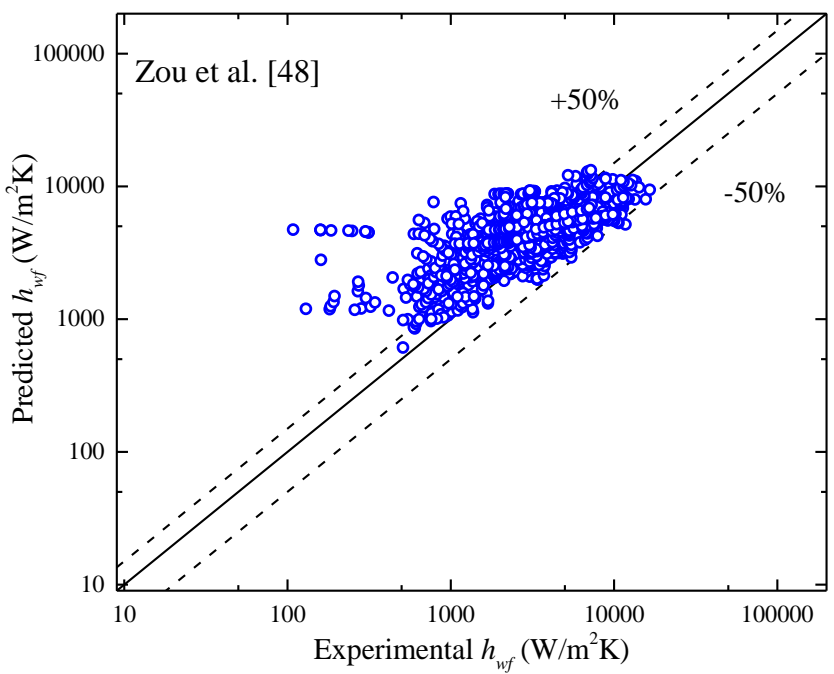

(i)

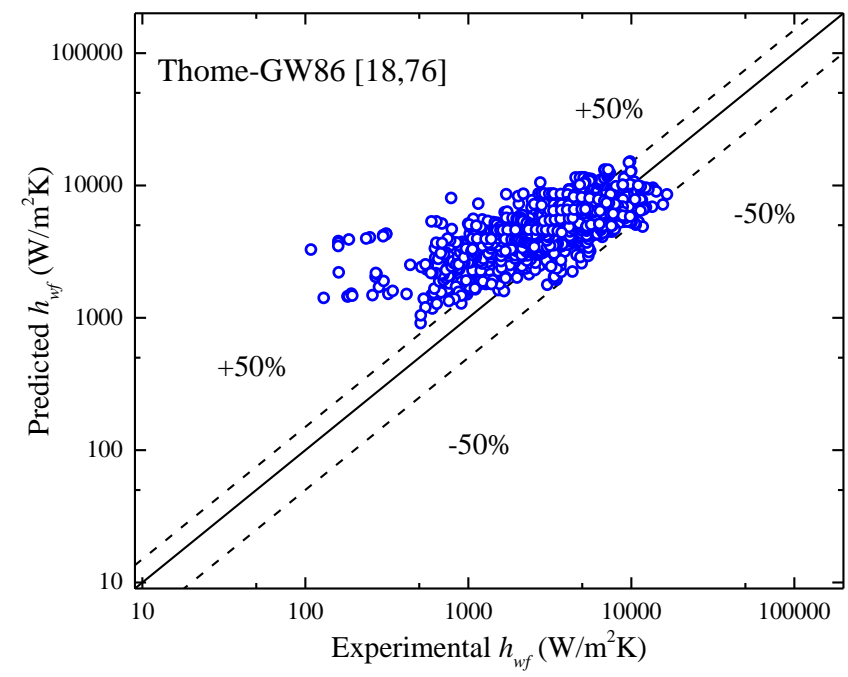

6

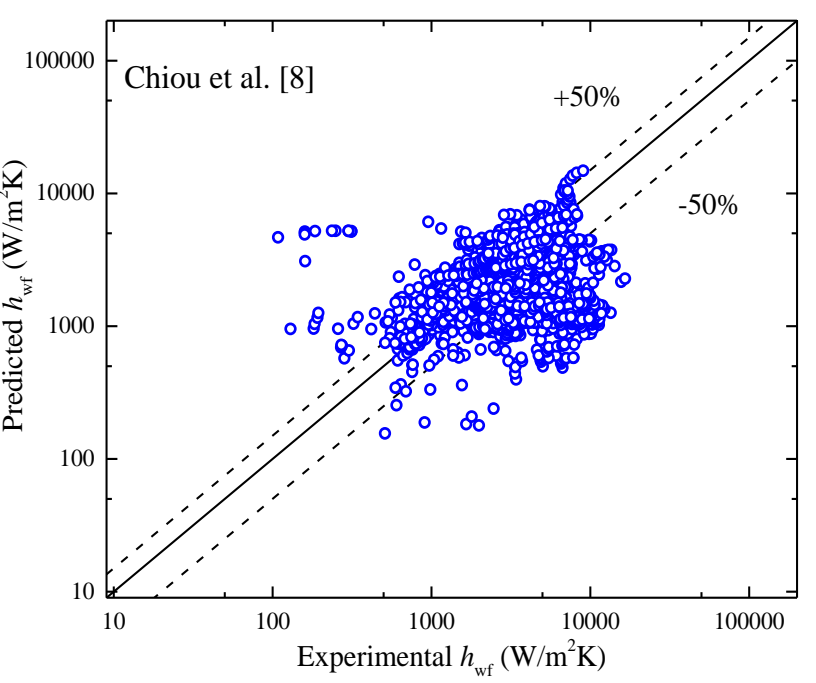

(h)

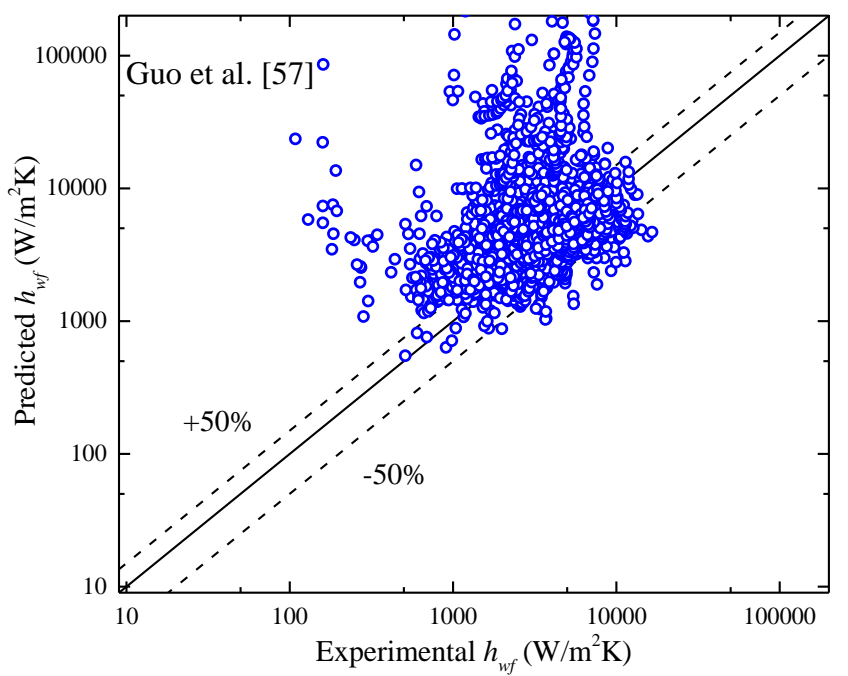

(j)

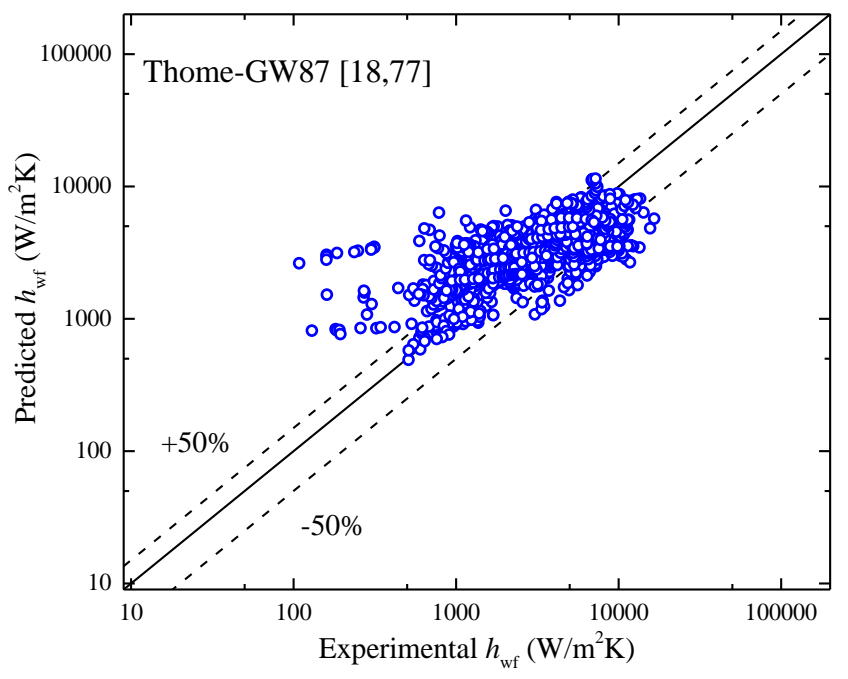

(1) 


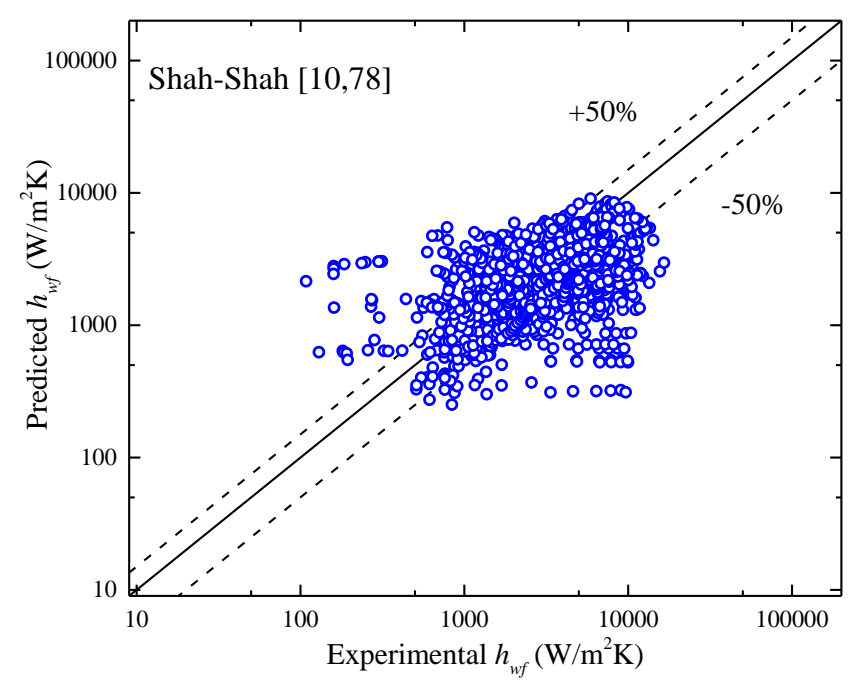

(m)

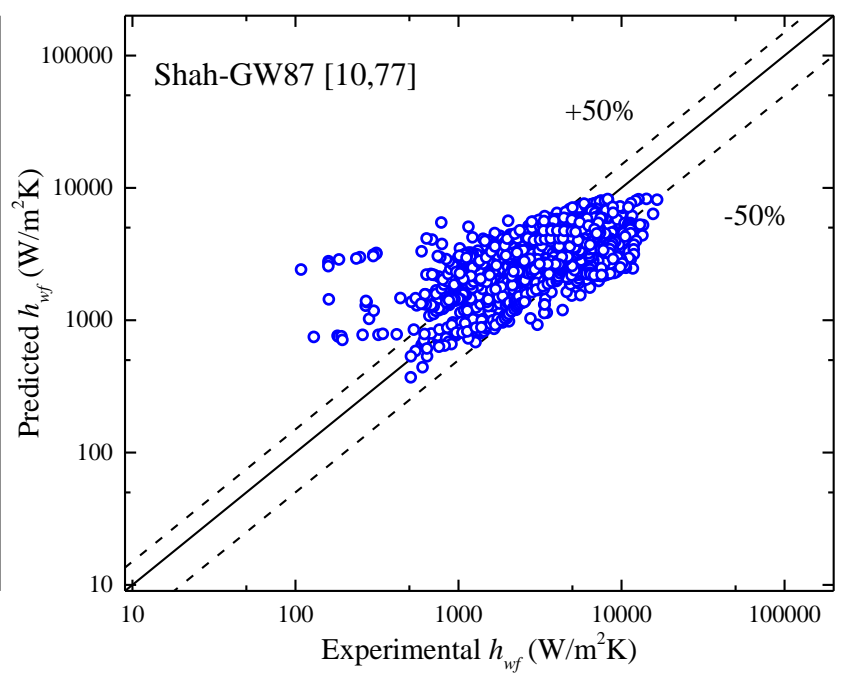

(n)
5 Figure 3 Predicted heat transfer coefficients calculated by the fifteen correlations presented in

6 Tables 2 and 3 versus experimental mixture flow boiling heat transfer coefficients from the database.

7 Table 4 Statistical parameters from the comparison of the correlations.

\begin{tabular}{|c|c|c|c|c|}
\hline & MAPD (\%) & MBPD (\%) & PCT30 (\%) & PCT50 (\%) \\
\hline \multicolumn{5}{|l|}{ Specific correlations } \\
\hline Mishra et al. [28] & 44.2 & -19.0 & 35.5 & 61.3 \\
\hline Jung et al. [6] & 122.6 & 113.5 & 36.1 & 56.3 \\
\hline Granryd [62] & 68.4 & 38.3 & 44.4 & 64.8 \\
\hline Takamatsu et al. [64] & 414.1 & 414.0 & 2.1 & 5.5 \\
\hline Bivens and Yokezeki [67] & 67.2 & 46.7 & 46.5 & 63.8 \\
\hline Shin et al. [29] & 86.2 & -85.9 & 0.6 & 1.1 \\
\hline Choi et al. [69] & 230.3 & 230.0 & 7.1 & 12.4 \\
\hline Chiou et al. [8] & 58.8 & 2.0 & 37.9 & 60.4 \\
\hline Zou et al. [48] & 77.8 & 69.9 & 43.6 & 59.9 \\
\hline Guo et al. [57] & 325.0 & 308.4 & 36.0 & 53.9 \\
\hline \multicolumn{5}{|l|}{ General correlations } \\
\hline Thome-GW86 [18,76] & 86.3 & 79.6 & 31.1 & 47.9 \\
\hline Thome-GW87 [18,77] & 49.0 & 27.3 & 56.1 & 73.4 \\
\hline Shah-Shah $[10,78]$ & 52.8 & -4.0 & 39.7 & 64.4 \\
\hline
\end{tabular}




\begin{tabular}{|l|l|l|l|l|}
\hline Shah-GW87 [10,77] & 47.3 & 11.4 & 48.9 & 73.1 \\
\hline Shah-LW [10,73] & 54.9 & 26.3 & 50.8 & 70.0 \\
\hline
\end{tabular}

In Figure 3 the predicted heat transfer coefficients calculated by the fifteen correlations are plotted against the experimental values from the database, and the statistical parameters from the comparison are shown in Table 4. From the comparison, the following conclusions are drawn:

- Generally, the general correlations enable better predictions than the specific correlations, indicating that the modification method proposed by Thome [18] and Shah [10] is effective.

- Most of the correlations overestimate the experimental data points, which may cause an insufficient heat transfer area in the evaporator if those correlations are used for the evaporator design.

- Mishra et al. [28], Thome-GW87 [18,77] and Shah-GW87 [10,77] are the only three correlations with a MAPD less than $50 \%$. Interestingly, all three correlations were developed using the enhancement model based on data either from annular flow, thereby belonging to the convective boiling region - Mishra et al. [28] correlation, or from the region where convective boiling is dominant - the base pure working fluid GW87 [77]. That is, all three correlations focus on the contribution of convective boiling, rather than that of nucleate boiling. Therefore, their good predictive ability suggests that the suppression of nucleate boiling due to the mixture mass diffusion effect leads to a more significant contribution of convective boiling in the mixture flow boiling process.

- However, considering that the lowest MAPD of $44.2 \%$ obtained by the correlation by Mishra et al. [28] is still higher than the prediction accuracy of $30 \%$ in engineering standards [79], a correlation with a better predictive performance needs to be developed.

\section{New heat transfer correlations}

The derivation of two mixture flow boiling heat transfer correlations is presented in this section. The first correlation was developed by modifying the existing correlations, considering physical phenomena and their prediction performances; see Table 4. The second correlation was derived using a dimensional analysis coupled with multiple regressions. The correlation which is derived by following the first approach will be entitled a physics-based correlation, while the correlation which is derived by following the second approach will be entitled a regression-based correlation.

\subsection{Physics-based correlation}


As shown in Section 2.3, the temperature glide $T_{g}$ plays an important role in the heat transfer process, i.e. a large temperature glide causes a great suppression of the nucleate boiling and hence leads to a more dominant contribution of the convective boiling part of the whole evaporation process. In addition to the temperature glide, the saturation temperature $T_{\text {sat }}$ also has a significant effect on the heat transfer process through its impact on the bubble nucleation. Specifically, the surface tension $\sigma$ decreases and the slope of the equilibrium vapor pressure curve $(\Delta P / \Delta T)_{s a t}$ increases with the saturation temperature, both contributing to increasing the number of active nucleation sites [80]. As a result, at higher saturation temperatures, the suppression of nucleate boiling tends to be less and nucleate boiling can be dominant in the whole heat transfer process. This phenomenon has been proven in the open literature, e.g. in Refs. [81,82]. Based on the aforementioned mechanisms, a dimensionless number $T^{*}$, the ratio of the temperature glide to the saturation temperature was introduced in this study:

$$
T^{*}=T_{g} / T_{\text {sat }}
$$

Based on this number, the physics-based correlation depending on the heat transfer region is expressed as

$$
\begin{gathered}
h_{\mathrm{tp}}=\left[\left(F_{c} h_{\text {Cooper_nb }}\right)^{2}+\left(h_{\text {Mishra }}\right)^{2}\right]^{0.5} T^{*} \leq 0.06, \\
h_{\mathrm{tp}}=\left[1+3000\left(F_{c} B o\right)^{0.86}+1.12\left(\frac{x}{1-x}\right)^{0.75}\left(\frac{\rho_{l}}{\rho_{v}}\right)^{0.41}\right] h_{l} \quad T^{*}>0.06 .
\end{gathered}
$$

In order to minimize the relative deviations of the predicted values, one region is defined for $T^{*} \leq$ 0.06 (Region I) to describe a concomitant process by nucleate and convective boiling, while the other region is defined for $T^{*}>0.06$ (Region II) to account for a process dominated by convective boiling. For Region I, an asymptotic model was employed and the correlation by Mishra et al. [28] (see Table 2) was used to calculate the heat transfer coefficient for the contribution of the convective boiling, as its derivation was based on data obtained for convective boiling with the lowest MAPD (44.2\%) among all the existing correlations. Moreover, Cooper [83] developed a pure working fluid correlation particularly for the nucleate boiling region in flow boiling by modifying the pool boiling correlation (Eq. (6)) with a factor of 0.7 , defined as

$$
h_{\text {Cooper_nb }}=35 M^{-0.5} q^{-0.67} P_{r}^{0.12}\left(-\log _{10} P_{r}\right)^{-0.55} \text {, }
$$

which is applied as the base pure working fluid correlation, multiplied by the mixture correction factor $F_{c}$ developed by Thome [18], to calculate the contribution of nucleate boiling in Eq. (24). For Region II, the Thome-GW87 correlation (see Eq. (25)) was directly employed as the prediction method has a good predictive performance for the data points within the region. 


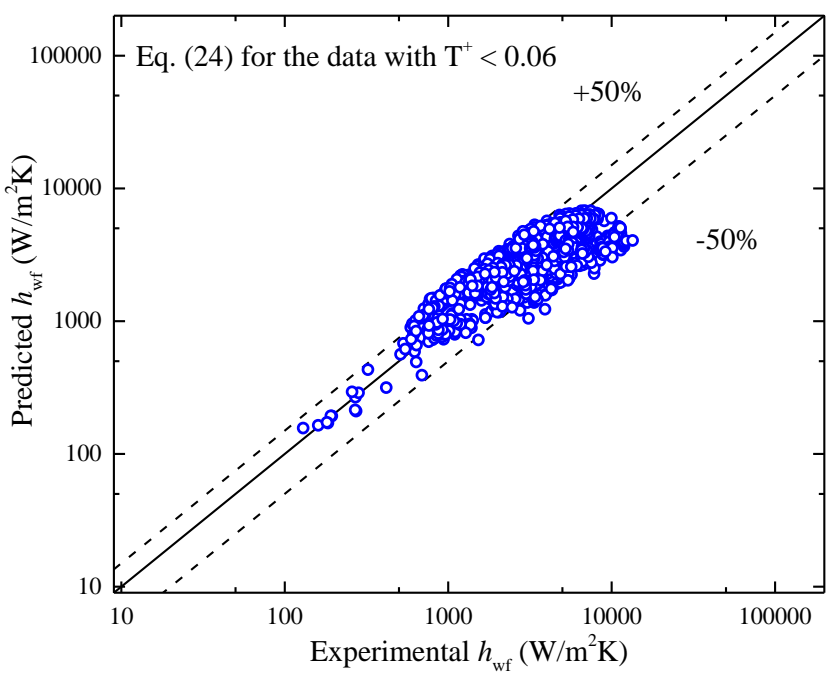

(a)

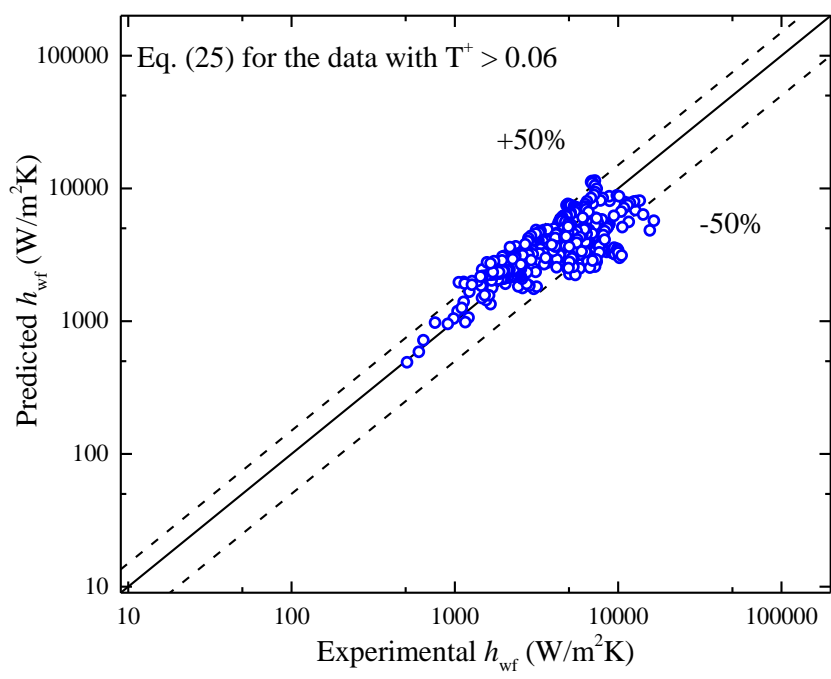

(b)

Figure 4 Predicted heat transfer coefficients using the physics-based correlation (Eqs. (24) and (25)) developed in this study versus the experimental mixture flow boiling heat transfer coefficients from the database.

The predicted heat transfer coefficients calculated by the physics-based correlation (Eqs. (24) and (25)) are plotted against the experimental data points in Figure 4, and the statistical parameters of the comparison are shown in Table 5. By comparing the four evaluation parameters of the new correlation with those of the selected existing correlations, it can be concluded that the predictive performance of the new correlation is significantly improved. Particularly, the MAPD for the new correlation is up to $29.0 \%$, falling within the engineering standard of $30 \%$.

Table 5 Prediction results of the correlations developed in this study for the data points.

\begin{tabular}{lllll}
\hline & MAPD (\%) & MBPD (\%) & PCT30 (\%) & PCT50 (\%) \\
\hline Physics-based correlation & & & & \\
Eq. (24) for data with $\mathrm{T}^{*} \leq 0.06$ & 28.8 & 2.8 & 58.2 & 81.3 \\
Eq. (25) for data with $\mathrm{T}^{*}>0.06$ & 29.5 & -4.3 & 54.7 & 84.5 \\
Total & 29.0 & -3.0 & 57.3 & 82.1 \\
\hline Regression-based correlation & & & & \\
Eq. (35) for data with T $\leq 0.06$ & 24.8 & 1.6 & 64.8 & 89.9 \\
Eq. (36) for data with $\mathrm{T}^{*}>0.06$ & 24.1 & 0.5 & 65.0 & 91.5 \\
Total & 24.6 & 1.4 & 64.9 & 90.1 \\
\hline
\end{tabular}

\subsection{Regression-based correlation}

The method adopted for the second approach has been used in several studies for developing heat transfer correlations $[84,85]$. Its basic idea is to perform a multiple regression of dimensionless numbers obtained from the independent variables using the Buckingham $\pi$ theory. In this study, seventeen variables were identified as being the most important parameters influencing the zeotropic mixture flow boiling heat transfer, and their relationship with the final heat transfer 
coefficient was defined as

$$
h_{t p}=f\left(D, \mu_{l}, \mu_{v}, \sigma,\left(\rho_{l}-\rho_{v}\right) g, q, h_{f g}, T_{g}, T_{s a t}, k_{l}, c_{p l}, c_{p m}, \rho_{l}, \rho_{v}, G, G_{l}, G_{v}\right) \text {, }
$$

where $G_{l}$ and $G_{v}$ are the mass flux of liquid phase and vapor phase, respectively, the gravitational term $\left(\rho_{l}-\rho_{v}\right) \mathrm{g}$ accounts for the buoyancy force, and the mean specific heat capacity of the liquid and vapor phases $c_{p m}$ is defined as

$$
c_{p m}=(1-x) c_{p l}+x c_{p v}
$$

which is used as an approximate estimate of the sensible heat transfer in a flow boiling process, as explained in Section 2.2.

Four primary dimensions are involved in the seventeen variables, namely, mass $\mathrm{kg}[\mathrm{M}]$, length $\mathrm{m}[\mathrm{L}]$, time $\mathrm{s}[\mathrm{t}]$, and temperature $\mathrm{K}[\mathrm{T}]$. Following the Buckingham $\pi$ theory, four variables able to cover the four primary dimensions were selected as follows:

$$
D[L], \rho_{l}\left[M L^{-3}\right], G\left[M L^{-2} t^{-1}\right], T_{g}[T] .
$$

Therefore, thirteen (seventeen minus four) dimensionless terms $\Pi_{i}(i=1-13)$ need to be developed. To this end, the four selected variables were integrated with each of the thirteen non-selected variables in Eq. (27):

$$
\Pi_{i}=D^{a} \rho_{l}^{b} G^{c} T_{g}{ }^{d} Z_{i}, i=1-13,
$$

where $z_{i}$ is the non-selected variable in Eq. (27). The four exponents $a, b, c$ and $d$ can be solved using the non-dimensionalization of $\Pi_{i}$, as follows:

$[\mathrm{M}]: \mathrm{b}+\mathrm{c}+M_{z_{i}}=0,[L]: a-3 b-2 c+L_{z_{i}}=0,[\mathrm{t}]:-\mathrm{c}+t_{z_{i}}=0,[\mathrm{~T}]: \mathrm{d}+T_{z_{i}}=0$,

where $M_{z_{i}}, L_{z_{i}}, t_{z_{i}}$ and $T_{z_{i}}$ are the exponents of variable $z_{i}$ in the four primary dimensions: mass, length, time and temperature, respectively. With the dimensional analysis, the thirteen dimensionless terms were defined as

$\Pi_{1}=\frac{\mu_{l}}{D G}, \Pi_{2}=\frac{\mu_{v}}{D G}, \Pi_{3}=\frac{\rho_{l} \sigma}{D G^{2}}, \Pi_{4}=\frac{\rho_{l}\left(\rho_{l}-\rho_{v}\right) g D}{G^{2}}, \Pi_{5}=\frac{\rho_{l}^{2} q}{G^{3}}, \Pi_{6}=\frac{\rho_{l}^{2} h_{f g}}{G^{2}}, \Pi_{7}=\frac{\rho_{l}^{2} T_{g} k_{l}}{G^{3} D}, \Pi_{8}=\frac{\rho_{l}^{2} c_{p l} T_{g}}{G^{2}}$, $\Pi_{9}=\frac{\rho_{l}^{2} c_{p m} T_{g}}{G^{2}}, \Pi_{10}=\frac{T_{g}}{T_{s a t}}, \Pi_{11}=\frac{\rho_{l}}{\rho_{v}}, \Pi_{12}=\frac{G_{l}}{G}, \Pi_{13}=\frac{G_{v}}{G}$.

In order to simplify the dimensionless group and make physical interpretations of the dimensionless parameters used for developing the correlation, the terms in Eq. (32) were combined and converted. Finally, eight well-known dimensionless numbers $\left(\varphi_{1}-\varphi_{8}\right)$ and two new dimensionless terms $\left(\varphi_{9}-\right.$ $\left.\varphi_{10}\right)$, which are related to the unique heat transfer mechanisms of the mixtures, were obtained: 
1

$\varphi_{1}=\Pi_{1}^{-1}=\frac{D G}{\mu_{l}}=R e_{l o}, \varphi_{2}=\Pi_{2}^{-1}=\frac{D G}{\mu_{v}}=R e_{v o}, \varphi_{3}=\Pi_{11} \Pi_{1}^{-1}=\frac{D G_{l}}{\mu_{v}}=R e_{l}$,

$\varphi_{4}=\Pi_{12} \Pi_{2}^{-1}=\frac{D G_{v}}{\mu_{v}}=R e_{v}, \varphi_{5}=\Pi_{3}^{-1}=\frac{D G^{2}}{\rho_{l} \sigma}=W e_{l}, \varphi_{6}=\Pi_{4}{ }^{-1} \Pi_{10} \Pi_{12}{ }^{2}=\frac{G_{v}{ }^{2}}{\rho_{v}\left(\rho_{l}-\rho_{v}\right) g D}=F r_{v}$,

$\varphi_{7}=\Pi_{5} \Pi_{6}^{-1}=\frac{q}{G h_{f g}}=B o, \varphi_{8}=\Pi_{7}^{-1} \Pi_{8} \Pi_{1}=\frac{c_{p l} \mu_{l}}{k_{l}}=P r_{l}, \varphi_{9}=\Pi_{9} \Pi_{6}^{-1}=\frac{c_{p v} T_{g}}{h_{f g}}=Q^{*}$,

$\varphi_{10}=\Pi_{10}=T^{*}$.

In Eq. (33), the four Reynolds numbers $R e_{l o}, R e_{v o}, R e_{l}$ and $R e_{v}$, (where the subscripts stand for liquid only, vapor only, liquid and vapor, respectively), represent the ratio of inertial to viscous forces in the fluid. The whole flows are considered as the liquid or vapor phase when calculating the mass flux term in $R e_{l o}$ or $R e_{v o}$, while only the liquid or vapor phase in the flow is considered for calculating the mass flux term in $R e_{l}$ or $R e_{v}$. The liquid Weber number $W e_{l}$ is commonly used when analyzing fluid flows where an interface exists, and it represents the relative importance of the fluid's inertia compared to its surface tension. The vapor Froude number $F r_{v}$, defined as the ratio of the flow inertia to the gravity field, is modified by the density ratio and adopted to quantify the transitions between flow pattern maps, e.g. in Ref. [86]. The boiling number $B o$ represents the ratio of the mass rate of vapor generated per unit area to mass flow rate per unit area (mass flux), quantifying the intensity of nucleate boiling. The liquid Prandtl number $\operatorname{Pr}_{l}$ is defined as the ratio of momentum diffusivity to thermal diffusivity in the liquid phase, representing the effect of the fluid's properties on heat transfer. The value of the ratio of the temperature glide to the saturation temperature $T^{*}$ governs the heat transfer mechanisms in mixture flow boiling (see Section 5.1). The dimensionless term $Q^{*}$ represents the ratio of the sensible heat to the latent heat in a complete flow boiling process (while the vapor quality changes from 0 to 1 ), governing the effects of sensible heat transfer on non-isothermal vaporization of mixture flow boiling.

A power law representation was employed to develop the correlation using the dimensionless terms in Eq. (33) with multiple regression analysis. The correlation is expressed as

$$
h_{t p}=C \cdot \varphi_{i}^{a_{i}} \cdot\left(\frac{k_{l}}{D}\right), i=1,2, \cdots \cdots, 10
$$

In addition, the two $T^{*}$-based regions presented in Section 5.1 were used here to improve the regression. After elimination of the dimensionless terms that did not improve the predictive ability of the correlation, the final correlations read

$$
\begin{aligned}
& h_{\mathrm{tp}}=20.1439 R e_{l}{ }^{0.1505} \mathrm{Re}_{v o}{ }^{0.4551} \mathrm{Bo}^{0.5580} \mathrm{Fr}_{v}{ }^{0.2538} T^{*-1.1466} Q^{* 1.1084}\left(\frac{k_{l}}{D}\right) T^{*} \leq 0.06, \\
& h_{\mathrm{tp}}=0.1672 W e_{l}^{-0.1457} \mathrm{Re}_{l}{ }^{0.4771} \mathrm{Re}_{v o}{ }^{0.1829} \mathrm{Fr}_{v}{ }^{0.1007} T^{*-0.2490} Q^{*-0.4878}\left(\frac{k_{l}}{D}\right) \quad T^{*}>0.06 .
\end{aligned}
$$

It is worth noting that the boiling number $B o$ has a significant effect on the heat transfer in Region I 
1 (a concomitant process by nucleate and convective boiling) while it is negligible in Region II,

2 which is a convective boiling dominated process. This shows consistency with its physical meaning,

3 i.e. representing the intensity of nucleate boiling. A comparison between the predicted heat transfer

4 coefficients calculated by the regression-based correlation (Eqs. (35) and (36)) and the experimental

5 heat transfer coefficients from the database is presented in Figure 5, and the statistical parameters of

6 the comparison are shown in Table 5. The prediction results shown in Table 5 indicate that this correlation can further improve the predictive ability by decreasing the MAPD to $24.6 \%$. Moreover,

\begin{tabular}{|c|c|c|c|c|c|c|c|}
\hline & $R e_{l}$ & $R e_{v o}$ & $B o$ & $F r_{v}$ & $T^{*}$ & $Q^{*}$ & $W e_{l}$ \\
\hline Eq. & $6.87 \cdot 10^{-1}-$ & $1.63 \cdot 10^{3}-$ & $2.03 \cdot 10^{-5}-$ & $4.75 \cdot 10^{-3}-$ & $1.63 \cdot 10^{-5}-$ & $2.29 \cdot 10^{-5}-$ & - \\
$(35)$ & $3.45 \cdot 10^{4}$ & $3.04 \cdot 10^{5}$ & $9.57 \cdot 10^{-3}$ & 1.24 & $5.99 \cdot 10^{-2}$ & $1.99 \cdot 10^{-1}$ & - \\
\hline
\end{tabular}

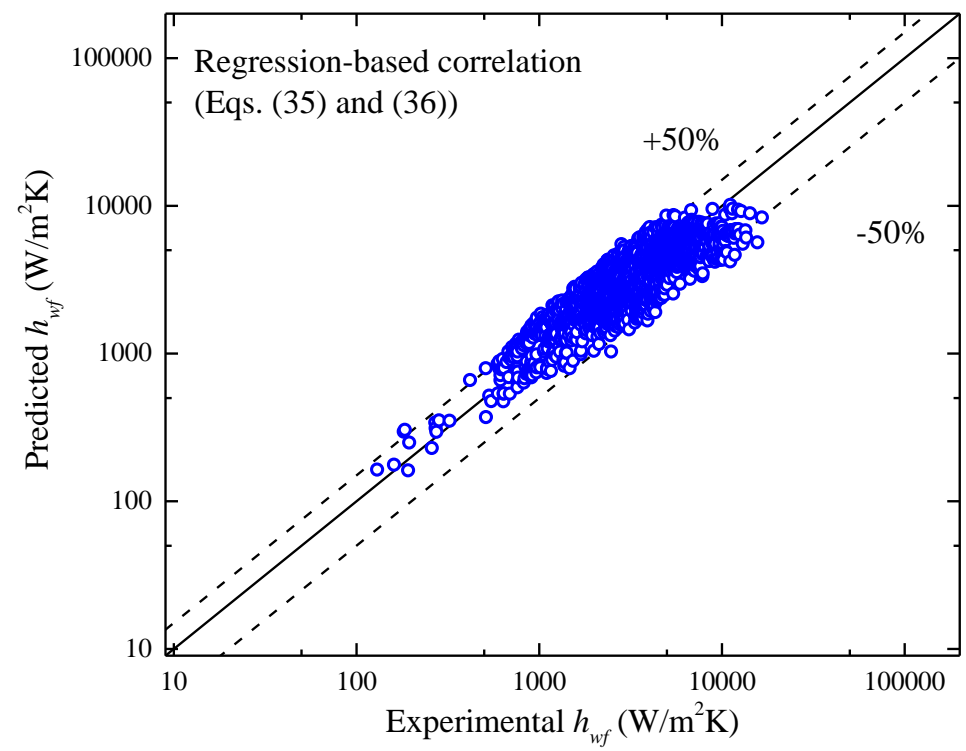

Figure 5 Predicted heat transfer coefficients calculated with the regression-based correlation (Eqs. (35) and (36)) developed in this study versus the experimental mixture flow boiling heat transfer coefficients from the database.

Due to the better predictive performance of the regression-based correlation, it is suggested to use it for predicting the heat transfer coefficient for working conditions falling in the ranges of the dimensionless for which the correlation was developed; the ranges are indicated in Table 6. If the working conditions are outside these ranges, the physics-based correlation is more appropriate for predicting the heat transfer coefficient, since it is based on physics rather than on data regression. However, validation of the two correlations by using more data points is expected to further demonstrate their predictive abilities.

Table 6. Range of dimensionless numbers in the regression-based correlation (Eqs. (35) and (36)). 


\begin{tabular}{c|c|c|c|c|c|c|c|}
\hline Eq. & $3.79 \cdot 10^{2}-$ & $1.61 \cdot 10^{4}-$ & - & $1.11 \cdot 10^{-2}-$ & $6.00 \cdot 10^{-2}-$ & $7.09 \cdot 10^{-2}-$ & $7.91 \cdot 10^{-3}-$ \\
$(36)$ & $2.57 \cdot 10^{4}$ & $4.41 \cdot 10^{4}$ & - & $9.16 \cdot 10^{-1}$ & $6.28 \cdot 10^{2}$ & $3.60 \cdot 10^{-1}$ & $2.82 \cdot 10^{2}$ \\
\hline
\end{tabular}

\section{Conclusions}

The current work included the development of a general heat transfer correlation capable of predicting the macroscale flow boiling heat transfer of zeotropic mixtures in horizontal plain tubes. The correlation is aimed at being used for the evaporator design in thermodynamic cycles using mixtures as working fluids.

The predicted heat transfer coefficients calculated by fifteen existing correlations selected from the open literature were compared with the experimental data points from a database including 2091 data points. The comparison results indicate that the correlations presented by Mishra et al. [28], Thome-GW87 [18,77] and Shah-GW87 [10,77] have the best predictive performance of the data points in the database, obtaining mean absolute percentage deviations of $44.2 \%, 49.0 \%$, and $47.3 \%$, respectively.

Two new correlations based on physics and regression, respectively, were developed. The two correlations are governed by two heat transfer regions characterized by a nucleate and convective boiling interacted process and a convective boiling dominated process, respectively. The physicsbased and regression-based correlations significantly improve the predictive performance for the database compared to the existing correlations selected in this paper, attaining mean absolute percentage deviations of $29.0 \%$ and $24.6 \%$, respectively. The regression-based correlation is suggested for use in cases with working conditions falling within the ranges of the dimensionless for which the correlation was developed; see Table 6. Outside these ranges, the physics-based correlation is more appropriate to use.

\section{Acknowledgement}

The research presented in this paper has received funding from the People Programme (Marie Curie Actions) of the European Union's Seventh Framework Programme (FP7/2007-2013) under the REA grant agreement $n^{\circ} 609405$ (COFUNDPostdocDTU), the European Union's Horizon 2020 research and innovation programme with a Marie Skłodowska-Curie Individual Fellowship under grant agreement No. 704201 (project NanoORC, http://www.nanoorc.mek.dtu.dk/), and Innovationsfonden with the THERMCYC project (www.thermcyc.mek.dtu.dk, project ID: 130500036B). The financial support is gratefully acknowledged. 


\section{References}

[1] M. Mohanraj, C. Muraleedharan, S. Jayaraj, A review on recent developments in new refrigerant mixtures for vapour compression-based refrigeration, air-conditioning and heat pump units., Int. J. Energy Res. 35 (2011) 647-669.

[2] A. Modi, F. Haglind, A review of recent research on the use of zeotropic mixtures in power generation systems, Energy Convers. Manag. 138 (2017) 603-626.

[3] B. Zühlsdorf, J.K. Jensen, S. Cignitti, C. Madsen, B. Elmegaard, Analysis of temperature glide matching of heat pumps with zeotropic working fluid mixtures for different temperature glides, Energy. 153 (2018) 650-660. doi:10.1016/j.energy.2018.04.048.

[4] R. Radermacher, Y. Hwang, Vapor compression heat pumps with refrigerant mixtures, CRC Press, 2005.

[5] M.P. Porto, H.T.C. Pedro, L. Machado, R.N.N. Koury, E.P. Bandarra Filho, C.F.M. Coimbra, Optimized heat transfer correlations for pure and blended refrigerants, Int. J. Heat Mass Transf. 85 (2015) 577-584. doi:10.1016/j.ijheatmasstransfer.2015.01.102.

[6] D.S. Jung, M. McLinden, R. Radermacher, D. Didion, A study of flow boiling heat transfer with refrigerant mixtures, Int. J. Heat Mass Transf. 32 (1989) 1751-1764. doi:10.1016/00179310(89)90057-4.

[7] A. Rabah, S. Kabelac, Flow Boiling of R134a and R134a/Propane Mixtures at Low Saturation Temperatures Inside a Plain Horizontal Tube, J. Heat Transfer. 130 (2008) 061501. doi:10.1115/1.2897345.

[8] C.B. Chiou, D.C. Lu, C.Y. Liao, Y.Y. Su, Experimental study of forced convective boiling for non-azeotropic refrigerant mixtures R-22/R-124 in horizontal smooth tube, Appl. Therm. Eng. 29 (2009) 1864-1871. doi:10.1016/j.applthermaleng.2008.09.004.

[9] S. Grauso, R. Mastrullo, A.W. Mauro, G.P. Vanoli, CO2 and propane blends: Experiments and assessment of predictive methods for flow boiling in horizontal tubes, Int. J. Refrig. 34 (2011) 1028-1039. doi:10.1016/j.ijrefrig.2011.03.001.

[10] M.M. Shah, A method for predicting heat transfer during boiling of mixtures in plain tubes, Appl. Therm. Eng. 89 (2015) 812-821. doi:10.1016/j.applthermaleng.2015.06.047.

[11] S. Kakaç, H. Liu, A. Pramuanjaroenkij, Heat Exchangers: Selection, Rating, and Thermal Design, Second Edi, CRC Press, Boca Raton, 2002.

[12] P.A. Kew, K. Cornwell, Correlations for the prediction of boiling heat transfer in smalldiameter channels, Appl. Therm. Eng. 17 (1997) 705-715. doi:10.1016/S13594311(96)00071-3.

[13] S. Nordtvedt, Performance analysis of a plate type heat exchanger used as absorber in a combined compression/absorption heat pump, in: Proc. Int. Sorption Heat Pump Conf., SCIENCE PRESS, Kjeller, Norway, 2002: pp. 235-239.

[14] S. Quoilin, M. Van Den Broek, S. Declaye, P. Dewallef, V. Lemort, Techno-economic survey of organic rankine cycle (ORC) systems, Renew. Sustain. Energy Rev. 22 (2013) 168-186. doi:10.1016/j.rser.2013.01.028.

[15] Ramesh K. Shah, Dušan P. Sekulic, Fundamentals of Heat Exchanger Design, John Wiley \& Sons, Inc., Hoboken, New Jersey, 2003.

[16] United States Environmental Protection Agency, Section 608 Technician Certification, (n.d.).

[17] R. Radermacher, Y. Hwang, Heat Transfer of Refrigerant Mixturers, in: Vap. Compression Heat Pumps with Refrig. Mix., Taylor \& Francis Group, LLC, 2005: pp. 237-278. 
doi:doi:10.1201/9781420037579.ch8.

[18] J.R. Thome, Boiling of new refrigerants: a state-of-the art review, Int. J. Refrig. 19 (1996) 435-457.

[19] K. Murata, K. Hashizume, An investigation on forced convection boiling of nonazeotropic refrigerant mixtures, Heat Transf. Japanese Res. 19 (1990) 95-109.

[20] D.S. Jung, M. Mclinden, R. Radermachert, D. Didion, Horizontal flow boiling heat transfer experiments with a mixture of R22 / R114, Int. J. Heat Mass Transf. 32 (1989) 131-145.

[21] E. Hihara, K. Tanida, T. Saito, Forced convective boiling experiments of binary mixtures, JSME Int. J. 32 (1989) 98-106. doi:https://doi.org/10.1299/jsmeb1988.32.1_98.

[22] R.L. WEBB, N.S. GUPTE, A Critical Review of Correlations for Convective Vaporization in Tubes and Tube Banks, Heat Transf. Eng. 13 (1992) 58-81.

[23] J.C. Chen, Correlation for boiling heat transfer to saturated fluids in convective flow, Ind. Eng. Chem. Process Des. Dev. 5 (1966) 322-329. doi:10.1021/i260019a023.

[24] F.P. Incropera, D.P. DeWitt, Introduction to Heat Transfer, John Wiley \& Sons, New York, NY, 1996.

[25] M.G. Cooper, Heat Flow Rates in Saturated Nucleate Pool Boiling-A Wide-Ranging Examination Using Reduced Properties, Adv. Heat Transf. 16 (1984) 157-239. doi:10.1016/S0065-2717(08)70205-3.

[26] K. Stephan, M. Abdelsalam, Heat-transfer correlations for natural convection boiling, Int. J. Heat Mass Transf. 23 (1980) 73-87. doi:10.1016/0017-9310(80)90140-4.

[27] M.M. Shah, A new correlation for heat transfer during boiling flow through pipes, Ashrae Trans. 82 (1976) 66-86.

[28] M.P. Mishra, H.K. Varma, C.P. Sharma, Heat transfer coefficients in forced convection evaporation of refrigerants mixtures, Lett. Heat Mass Transf. 8 (1981) 127-136. doi:10.1016/0094-4548(81)90034-5.

[29] J.Y. Shin, M.S. Kim, S.T. Ro, Correlation of Evaporative Heat Transfer Coefficients for Refrigerant Mixtures, Int. Refrig. Air Cond. Conf. (1996) 151-156.

[30] E.W. Lemmon, M.L. Huber, M.O. McLinden, NIST reference fluid thermodynamic and transport properties-REFPROP, NIST Stand. Ref. Database 23. (2002).

[31] I.H. Bell, E.W. Lemmon, Automatic fitting of binary interaction parameters for multi-fluid Helmholtz-energy-explicit mixture models, J. Chem. Eng. Data. 61 (2016) 3752-3760.

[32] S.A. Klein, M.O. McLinden, A. Laesecke, An improved extended corresponding states method for estimation of viscosity of pure refrigerants and mixtures, Int. J. Refrig. 23 (1997) 208-217.

[33] M.O. McLinden, S.A. Klein, R.A. Perkins, An extended corresponding states model for the thermal conductivity of refrigerants and refrigerant mixtures, Int. J. Refrig. 23 (2000) 43-63.

[34] A. Mulero, I. Cachadiña, Recommended correlations for the surface tension of several fluids included in the REFPROP program, J. Phys. Chem. Ref. Data. 43 (2014) 023104.

[35] M. Niederkrüger, D. Steiner, E.U. Schlünder, Horizontal flow boiling experiments of saturated pure components and mixtures of R846-R12 at high pressures, Int. J. Refrig. 15 (1992) 48-58. doi:10.1016/0140-7007(92)90067-5.

[36] K. Murate, K. Hashizume, Forced convective boiling of nonazeotropic refrigerant mixtures inside tube, J. Heat Transfer. 115 (1993) 680-689. 
[37] C.C. Wang, C.S.. Kuo, Y.J. Chang, D.C. Lu, Two-phase flow heat transfer and friction characteristics of R-22 and R-407C, Ashrae Trans. 102 (1996) 830-838.

[38] C. Wang, C. Chiang, Two-phase heat transfer characteristics for R-22/R-407C in a $6.5 \mathrm{~mm}$ smooth tube, Int. J. Heat Fluid Flow. 18 (1997) 550-558.

[39] L. Zhang, E. Hihara, T. Saito, J.T. Oh, Boiling heat transfer of a ternary refrigerant mixture inside a horizontal smooth tube, Int. J. Heat Mass Transf. 40 (1997) 2009-2017. doi:10.1016/S0017-9310(96)00301-8.

[40] J.Y. Shin, M.S. Kim, S.T. Ro, Experimental study on forced convective boiling heat transfer of pure refrigerants and refrigerant mixtures in a horizontal tube, Int. J. Refrig. 20 (1997) 267-275. doi:10.1016/S0140-7007(97)00004-2.

[41] X. Boissieux, M.R. Heikal, R.A. Johns, Two-phase heat transfer coefficients of three HFC refrigerants inside a horizontal smooth tube, part I: evaporation, Int. J. Refrig. 23 (2000) 269-283.

[42] M. Wettermann, D. Steiner, Flow boiling heat transfer characteristics of wide-boiling mixtures, Int. J. Therm. Sci. 39 (2000) 225-235. doi:10.1016/S1290-0729(00)00241-6.

[43] M. Lallemand, C. Branescu, P. Haberschill, Local heat transfer coe cients during boiling of R22 and R407C in horizontal smooth and microfin tubes, Int. J. Refrig. 24 (2001) 57-72. doi:10.1016/S0140-7007(00)00064-5.

[44] J.C. Passos, V.F. Kuser, P. Haberschill, M. Lallemand, Convective boiling of R-407c inside horizontal microfin and plain tubes, Exp. Therm. Fluid Sci. 27 (2003) 705-713. doi:10.1016/S0894-1777(02)00308-4.

[45] A. Greco, Convective boiling of pure and mixed refrigerants: An experimental study of the major parameters affecting heat transfer, Int. J. Heat Mass Transf. 51 (2008) 896-909. doi:10.1016/j.ijheatmasstransfer.2007.11.002.

[46] B. Raja, D. Mohan Lal, R. Saravanan, Flow boiling heat transfer study of R-134a/R-290/R600a mixture in 9.52 and $12.7 \mathrm{~mm}$ smooth horizontal tubes: Experimental investigation, Exp. Therm. Fluid Sci. 33 (2009) 542-550. doi:10.1016/j.expthermflusci.2008.11.007.

[47] X. Zou, M. Gong, G. Chen, Z. Sun, J. Wu, Experimental study on saturated flow boiling heat transfer of R290/R152a binary mixtures in a horizontal tube, Front. Energy Power Eng. China. 4 (2010) 527-534. doi:10.1007/s11708-010-0109-7.

[48] X. Zou, M.Q. Gong, G.F. Chen, Z.H. Sun, Y. Zhang, J.F. Wu, Experimental study on saturated flow boiling heat transfer of R170/R290 mixtures in a horizontal tube, Int. J. Refrig. 33 (2010) 371-380. doi:10.1016/j.ijrefrig.2009.10.013.

[49] J.M. Cho, Y.J. Kim, M.S. Kim, Experimental studies on the characteristics of evaporative heat transfer and pressure drop of $\mathrm{CO} 2 /$ propane mixtures in horizontal and vertical smooth and micro-fin tubes, Int. J. Refrig. 33 (2010) 170-179. doi:10.1016/j.ijrefrig.2009.09.009.

[50] M. Li, C. Dang, E. Hihara, Flow boiling heat transfer of HFO1234yf and R32 refrigerant mixtures in a smooth horizontal tube: Part I. Experimental investigation, Int. J. Heat Mass Transf. 55 (2012) 3437-3446. doi:10.1016/j.ijheatmasstransfer.2012.03.002.

[51] M. Anowar Hossain, Y. Onaka, H.M.M. Afroz, A. Miyara, Heat transfer during evaporation of R1234ze(E), R32, R410A and a mixture of R1234ze(E) and R32 inside a horizontal smooth tube, Int. J. Refrig. 36 (2013) 465-477. doi:10.1016/j.ijrefrig.2012.10.009.

[52] A. Kundu, R. Kumar, A. Gupta, Comparative experimental study on flow boiling heat transfer characteristics of pure and mixed refrigerants, Int. J. Refrig. 45 (2014) 136-147. 
doi:10.1016/j.ijrefrig.2014.05.023.

[53] A. Kundu, R. Kumar, A. Gupta, Flow boiling heat transfer characteristics of R407C inside a smooth tube with different tube inclinations, Int. J. Refrig. 45 (2014) 1-12. doi:10.1016/j.ijrefrig.2014.06.009.

[54] J. Qiu, H. Zhang, X. Yu, Y. Qi, J. Lou, X. Wang, Experimental investigation of flow boiling heat transfer and pressure drops characteristic of R1234ze(E), R600a, and a mixture of R1234ze(E)/R32 in a horizontal smooth tube, Adv. Mech. Eng. 7 (2015) 1-12. doi:10.1177/1687814015606311.

[55] Y. Zhu, X. Wu, Z. Wei, Heat transfer characteristics and correlation for CO2/propane mixtures flow evaporation in a smooth mini tube, Appl. Therm. Eng. 81 (2015) 253-261. doi:10.1016/j.applthermaleng.2015.02.009.

[56] R. Barraza, G. Nellis, S. Klein, D. Reindl, Measured and predicted frictional pressure drop for boiling zeotropic mixed refrigerants in horizontal tubes, Int. J. Heat Mass Transf. 98 (2016) 285-298. doi:10.1016/j.ijheatmasstransfer.2016.03.010.

[57] C. Guo, J. Wang, X. Du, L. Yang, Experimental flow boiling characteristics of R134a/R245fa mixture inside smooth horizontal tube, Appl. Therm. Eng. 103 (2016) 901908. doi:10.1016/j.applthermaleng.2016.04.162.

[58] D.L. Bennett, J.C. Chen, Forced convective boiling in vertical tubes for saturated pure components and binary mixtures, AIChE J. 26 (1980) 454-461. doi:10.1002/aic.690260317.

[59] S.G. Kandlikar, Boiling Heat Transfer With Binary Mixtures : Part I I — Flow Boiling in Plain Tubes, 120 (1998) 388-394.

[60] M. Li, C. Dang, E. Hihara, Flow boiling heat transfer of HFO1234yf and HFC32 refrigerant mixtures in a smooth horizontal tube: Part II. Prediction method, Int. J. Heat Mass Transf. 64 (2013) 591-608. doi:10.1016/j.ijheatmasstransfer.2013.04.047.

[61] H.C. Ünal, Prediction of nucleate pool boiling heat transfer coefficients for binary mixtures, Int. J. Heat Mass Transf. 29 (1986) 637-640.

[62] E. Granryd, Heat transfer in flow evaporation of non-azeotropic refrigerant mixtures - A theoretical approach, in: Proc. 18th Int. Congr. Refrig., Montreal, 1991: pp. 1330-1334.

[63] K.J. Bell, M.A. Ghaly, An approximate generalized design method for multicomponent/partial condensers, AIChE Symp. Ser. 69 (1973) 72-79.

[64] H. Takamatsu, S. Momoki, T. Fujii, A correlation for forced convective boiling heat transfer of nonazeotropic refrigerant mixture of $\mathrm{HCFC} 22 / \mathrm{CFC} 114$ in a horizontal smooth tube, Int. J. Heat Mass Transf. 36 (1993) 3555-3563. doi:10.1016/0017-9310(93)90173-4.

[65] D.S.. Jung, D.. Didion, Horizontal-flow boiling heat transfer using refrigerant mixtures: Final report, United States, 1989.

[66] H. Takamatsu, S. Momoki, T. Fujii, A correlation for forced convective boiling heat transfer of pure refrigerants in a horizontal smooth tube, Int. J. Heat Mass Transf. 36 (1993) 33513360. doi:10.1016/0017-9310(93)90016-Y.

[67] D.B. Bivens, A. Yokozeki, Heat transfer coefficients and transport properties for alternative refrigerants, in: Proceeding Int. Ref. Air Cond. Conf., Purdu, Indiana, United States, 1994: pp. 299-304. http://docs.lib.purdue.edu/iracc.

[68] J.P. Wattelet, J.C. Chato, A.L. Souza, B.R. Christofferson, Initial Condensation Comparison of R-22 With R-134a and R-321/R-125, 1993.

[69] T.Y. Choi, Y.J. Kim, M.S. Kim, S.T. Ro, Evaporation heat transfer of R-32, R-134a, R- 
32/134a, and R-32/125/134a inside a horizontal smooth tube, Int. J. Heat Mass Transf. 43 (2000) 3651-3660. doi:10.1016/S0017-9310(00)00005-3.

[70] J.R. Thome, S. Shakir, A new correlation for nucleate pool boiling of aqueous mixtures, AIChE Symp. Ser. 83 (1984) 46-51.

[71] V.V. Wadekar, Flow boiling-a simple correlation for convective heat transfer component, in: 9th Int. Heat Transf. Conf., Jerusalem, Israel, 1990: pp. 87-91.

[72] C. Chiou, D. Lu, C. Wang, Investigations of pool boiling heat transfer of binary refrigerant mixtures, Heat Transf. Eng. 18 (1997). doi:10.1080/01457639708939902.

[73] Z. Liu, R.H.S. Winterton, A general correlation for saturated and subcooled flow boiling in tubes and annuli, based on a nucleate pool boiling equation, Int. J. Heat Mass Transf. 34 (1991) 2759-2766. doi:10.1016/0017-9310(91)90234-6.

[74] J.R. Thome, Prediction of in-tube boiling of mixtures in vertical thermosyphon reboilers, in: 16th HTFS Res. Symp., Heriot- Watt University. Edinburgh (1986), 1986.

[75] K.J. Bell, A.M. Ghaly, An approximate generalized design method for multicomponent/partial condenser, AIChE Symp. Ser. 69 (1973) 72-79.

[76] K.E. Gungor, R.H.S. Winterton, A general correlation for flow boiling in tubes and annuli, Int. J. Heat Mass Transf. 29 (1986) 351-358. doi:10.1016/0017-9310(86)90205-X.

[77] K.E. Gungor, R.H.S. Winterton, Simplified general correlation for saturated flow boiling and comparisons of correlations, Chem. Eng. Res. Des. 65 (1987) 148-156.

[78] M.M. Shah, Chart correlation for saturated boiling heat transfer: equations and further study, ASHRAE Trans. 88 (1982) 185-196.

[79] J.R. Thome, R.L. Amalfi, F. Vakili-farahani, Two-phase Heat Transfer and Pressure Drop within Plate Heat Exchangers, in: Encycl. Two-Phase Heat Transf. Flow II, 2015: pp. 145215.

[80] D. Gorenflo, D. Kenning, Pool boiling, in: VDI Heat Atlas, Second Edi, Springer, 2010: pp. 757-792.

[81] H. Ross, R. Radermacher, M. di Marzo, D. Didion, Horizontal flow boiling of pure and mixed refrigerants, Int. J. Heat Mass Transf. 30 (1987) 979-992. doi:10.1016/00179310(87)90016-0.

[82] J. Zhang, A. Desideri, M.R. Kærn, T.S. Ommen, J. Wronski, F. Haglind, Flow boiling heat transfer and pressure drop characteristics of R134a, R1234yf and R1234ze in a plate heat exchanger for organic Rankine cycle units, Int. J. Heat Mass Transf. 108 (2017) 1787-1801. doi:10.1016/j.ijheatmasstransfer.2017.01.026.

[83] M.G. Cooper, Flow boiling-the "apparently nucleate" regime, Int. J. Heat Mass Transf. 32 (1989) 459-464. doi:10.1016/0017-9310(89)90133-6.

[84] R.L. Amalfi, F. Vakili-Farahani, J.R. Thome, Flow boiling and frictional pressure gradients in plate heat exchangers. Part 2: Comparison of literature methods to database and new prediction methods, Int. J. Refrig. 61 (2016) 185-203. doi:10.1016/j.ijrefrig.2015.07.009.

[85] A. Jokar, M.H. Hosni, S.J. Eckels, Dimensional analysis on the evaporation and condensation of refrigerant R-134a in minichannel plate heat exchangers, Appl. Therm. Eng. 26 (2006) 2287-2300. doi:10.1016/j.applthermaleng.2006.03.015.

[86] Y. Taitel, A.E. Dukler, A model for predicting flow regime transitions in horizontal and near horizontal gas-liquid flow, AIChE J. 22 (1976) 47-55. doi:10.1002/aic.690220105. 